\title{
How Cultural Capital Emerged in Gilded Age America: Musical Purification and Cross-Class Inclusion at the New York Philharmonic ${ }^{1}$
}

\author{
Fabien Accominotti \\ London School of Economics
}

\author{
Adam Storer \\ University of California, Berkeley
}

Shamus R. Khan
Columbia University

This article uses a new database of subscribers to the New York Philharmonic to explore how high culture became a form of socially valuable capital in late-19th-century America. The authors find support for the classic account of high culture's purification and exclusiveness, showing how over the long Gilded Age the social elite of New York attended the Philharmonic both increasingly and in more socially patterned ways. Yet they also find that the orchestra opened up to a new group of subscribers hailing from an emerging professional, managerial, and intellectual middle class. Importantly, the inclusion of this new audience was segregated: they did not mingle with elites in the concert hall. This segregated inclusion paved a specific way for the constitution of cultural capital. It meant that greater purity and greater inclusiveness happened together, enabling elite cultural participation to remain distinctive while elite tastes acquired broader social currency.

Edith Wharton's classic Gilded Age novel, The Age of Innocence, begins at the opera. The opening paragraphs describe the excitement throughout New York society at hearing the Swedish soprano Christine Nilsson sing

\footnotetext{
${ }^{1}$ This project would not have been possible without the support of the Andrew W. Mellon Foundation or the guidance of Barbara Haws and her team at the New York Philharmonic archives. Too many scholars commented on earlier drafts to directly thank each
}

(C) 2018 by The University of Chicago. All rights reserved. 0002-9602/2018/12306-0005\$10.00 
the role of Marguerite in Gounod's Faust. With an air of refinement, the narrator dismisses the crass culture of New Yorkers and praises the "sophisticated countenance" of Nilsson as she sings the emotional peak of the opera, "Il m'aime! Il m'aime! Quel trouble en mon coeur!" The protagonist, Newland Archer, enters his box just in time to hear these lines. Yet we never quite learn what Archer thinks of the soprano, for his attention quickly moves away from the stage to the rest of those sitting in the hall itself. Scanning the seats, his eyes settle on his fiancée's family box. A cousin, recently separated from her husband, sits among them. This minor scandal sets into motion a series of events that mark, for Wharton, an end of New York's innocence.

In this article we transport our reader into a New York concert hall in the late Gilded Age, and we use that setting to explore the emergence of cultural capital during this critical moment of American social history. Like most scholars of culture in that era, we are interested in what was being played on stage. But like Wharton, we suggest that the action of these cultural performances was also in the seats that enveloped the hall.

A long sociological tradition outlines how the consumption of culture can help groups define themselves socially and symbolically demarcate themselves from other groups in society (Bourdieu 1984; Lamont and Lareau 1988; Lamont and Fournier 1992). Scholars also note that the command of legitimate cultural references can grant access to other social resources. Yet sociology has been comparatively quiet on the question of the emergence of cultural capital — that is, on how high culture and its consumption became resources endowing social status in the first place. This article takes a provisional step toward asking how, in the American context, high culture was constituted as a form of socially valuable capital.

Existing accounts of the emergence of cultural capital focus on the core idea of an alignment between classes of objects and classes of people. What kind of people and what kind of cultural objects "go together" helps delineate classificatory boundaries that endow certain objects with the power to convey social status. One usually thinks of the mechanisms behind these alignments between objects and people as mechanisms of purification and exclusion (DiMaggio 1982a, 1982b; Levine 1988). As a set of cultural objects is purified from other, less "highbrow" objects, the set of people associated with these objects is narrowed and more starkly defined, through the ex-

one, but we would like to particularly acknowledge the outstanding $A J S$ reviewers, as well as Peter Bearman, Sven Beckert, Amy Binder, Paul DiMaggio, Ivan Ermakoff, Herb Gans, Fletcher Haulley, Victoria Johnson, Bill Weber, and our team of undergraduate research assistants. Direct correspondence to Fabien Accominotti, London School of Economics, Houghton Street, London, WC2A 2AE, United Kingdom. Email: f.accominotti@ lse.ac.uk 
clusion of others. Purification in the realm of objects breeds social closure in the realm of groups (Weber 1978; Parkin 1979), and the distinctiveness of culture allows it to become a resource for social status: its value comes from the fact that it is not shared.

Within the scholarship on the United States, accounts of the emergence of high culture as a resource for elite status also have a common empirical foundation: they argue that this process happened in the Gilded Age (DiMaggio 1982a, 1982b; Levine 1988; Beckert 2000; Benzecry 2014). It was during this moment that the American upper class took strength in the distinctiveness of its cultural endeavors, helping to define a new regime of social inequality.

This article focuses on a dominant cultural institution during the Gilded Age. Using a new database of subscribers to the New York Philharmonic, we examine attendance data to complement traditional accounts of how culture emerged as a resource for elite status in that era. Our analyses are made possible by the existence of a remarkable set of business records, from which we are able to reconstruct who subscribed to the Philharmonic, where they sat in the concert hall, and where they lived in the city throughout our period of interest. We find that over time attending the Philharmonic became both increasingly distinctive and increasingly inclusive. At a time when elite culture in the United States is thought to have become more distinctive through processes of purification and closure, we show that one of New York's main cultural institutions began to include a new group that did not share the attributes of more elite patrons.

By documenting changes in participation to one of the oldest and most prestigious orchestras in the United States at a key moment in the institutionalization of high culture, this article makes two contributions. First, it provides empirical evidence for a previously underemphasized process whereby culture emerged as a resource for elite status. Specifically, we show that in the Gilded Age the Philharmonic was remarkably successful at enlisting a rising, educated middle class among its audience members. While this does not disprove traditional accounts insisting on mechanisms of purification and exclusion, it highlights how the transformation of elite culture into a form of socially valuable capital also happened through processes of cross-class inclusion. Our account here factors in the growing differentiation of U.S. society in the Gilded Age: beside the consolidation of an American bourgeoisie, that period was witness to the emergence of a professional, managerial, and intellectual class of individuals who did not share the wealth or ancestry of the social elite (Chandler 1977; Gouldner 1979; Beckert 2000).

The inclusion of that educated class into elite-sponsored institutions offered a particularly apt answer to the challenges of turning high culture into a form of socially valuable capital. As students of culture have observed, privileged access to elite culture sustains the status of elites only to the extent 
that other social groups are also willing to participate in it (Bourdieu 1984). Thus, while some cultural exclusivity can convey upper-class distinction, a fully unshared culture comes at the risk of irrelevance: it threatens the broader currency of elite cultural endeavors. In Gilded Age New York, the emergence of a professional and intellectual middle class meant that elite culture could be shared and legitimized while remaining exclusive of lesser social groups. ${ }^{2}$

It is important to note that the inclusion of middle-class, educated subscribers within the audience of the Philharmonic was not complete integration. Instead - and this is our second contribution-we show that inclusion was segregated. By analyzing the evolution of sitting patterns in the concert hall, we find that throughout the Gilded Age the elite increasingly distinguished themselves by sitting in seats that differed from those of newly included subscribers. This is what we refer to as segregated inclusion-a form of inclusion in which new types of boundaries emerge between previously separate groups. In our case, the way in which elites enjoyed culture-as opposed to the culture that they enjoyed-increasingly demarcated them from middle-class newcomers, delineating a new dimension of distinction for an otherwise more inclusive environment.

Although this article focuses on New York City, the processes we describe were likely present elsewhere. They may have been more consequential in New York because of the specific circumstances of elites in that city. In particular, New York's upper class was generally more fragmented, less educated, and less culturally authoritative than its counterpart in Boston (Jaher 1982; DiMaggio 1991). One might therefore argue that just as Boston's uniquely cohesive and highly educated upper class made it the exemplary case of the constitution of cultural capital through powerful elite cultural entrepreneurship (DiMaggio 1982a, 1982b), New York's uniquely fluid elite made it the exemplary case of the constitution of cultural capital through processes of cross-class inclusion. These differences aside, however, we believe that the formation of a professional and intellectual middle class in U.S. cities in the Gilded Age was central to the constitution of a specifically American version of cultural capital.

We proceed by first outlining processes of cultural purification and exclusion in greater detail and by elaborating how in a context of social differentiation the constitution of cultural capital could follow from inclusion rather than exclusion. As background we describe how in the Gilded Age the social elite of New York departed from its Boston counterpart in its makeup, cohesiveness, and education. We then introduce the New York Philharmonic

\footnotetext{
${ }^{2}$ Beckert (2000, pp. 325-26) describes a similar alliance between the urban elite and the educated middle class as a response to the broader "crisis of legitimacy" of economic and political elites in the early 20th century. This alliance, he argues, was at the root of American progressivism.
} 
and our data sources. The second half of the article uses these data to describe transformations in the population of subscribers in the late Gilded Age, and shifting sitting patterns in the concert hall, reflecting the segregated inclusion of an educated middle class. We discuss the identity of these newly included subscribers and how they demand we think anew about how culture emerged and worked as a resource for elite status in late 19thcentury America.

\section{THEORY AND BACKGROUND}

Purification, Exclusion, and the Emergence of Cultural Capital in Gilded Age America

During the second half of the 19th century, the United States rapidly industrialized and urbanized; it experienced massive immigration from Europe; and it witnessed the rise of large and powerful corporations and the accumulation of unprecedented fortunes built on the profits of the second industrial revolution (Chandler 1977; Trachtenberg [1982] 2007; Licht 1995; Roy 1999). These transformations presented major challenges to the established American elite. As Levine (1988, p. 176) vividly conveys, "In an industrializing, urbanizing nation absorbing millions of immigrants from alien cultures and experiencing an almost incomprehensible degree of cultural change and spatial mobility, with anonymous institutions becoming ever larger and more central and with populations shifting from the countryside and small town to the city, from city to city, and from one urban neighborhood to another," the old elite was seized with a sense "of anarchic change, of looming chaos, of fragmentation, which seemed to imperil the very basis of the traditional order."

Historians and sociologists argue that as a response to these threats, the American elite in the Gilded Age consolidated into an upper class by closing ranks spatially, socially, and culturally. Through neighborhood closure, the cultivation of distinctive tastes, and participation in exclusive social clubs and institutions, elites insulated themselves from an increasingly tumultuous society and became a more coherent class by coalescing along a range of social and cultural dimensions (Almond [1939] 1998; Baltzell 1958; Story 1980; Jaher 1982; Beisel 1997; Beckert 2000). ${ }^{3}$

\footnotetext{
${ }^{3}$ A version of this argument was already articulated in Thorstein Veblen's Theory of the Leisure Class ([1899] 2009), which as early as 1899 satirized the old American elite for its withdrawal into the realm of etiquette and refined culture. The obsession of old patrician families with form and manners is also central to Edith Wharton's Gilded Age novels. Both Wharton and Veblen, however, regarded these trends as increasing the irrelevance of the traditional elite and precipitating its unseating by a rising group of newly moneyed industrialists.
} 


\section{American Journal of Sociology}

This account of the Gilded Age has often served as an empirical backdrop for theorizing the constitution of culture into cultural capital. While a long sociological tradition shows how the consumption of highbrow cultural goods helps elites to draw social and symbolic boundaries between themselves and other groups (Bourdieu 1984; Lamont and Lareau 1988; Lamont and Fournier 1992), scholars have also documented the mechanisms whereby elite culture emerged and acquired its distinctive status. ${ }^{4}$ In the United States, this happened through the gradual separation between high and popular culture, a process that took place in the Gilded Age (Green 1966; Horowitz 1976; DiMaggio 1982a, 1982b; Levine 1988; for a similar movement in Europe, see Weber [2001, 2008]). Described by Levine as the sacralization of high culture and by DiMaggio as its purification from popular elements, that process affected museums' collections as well as the repertoires of theaters and orchestras. While prior to the 1870 s culture was ordinarily consumed in venues offering a mixing of genres, toward the end of the century such mixing had virtually disappeared from elite cultural institutions. This purification of high culture resulted in the exclusion of working-class groups from these institutions and in the greater distinctiveness of high-culture consumption.

In Boston in particular, that shift was made possible by the control of a cohesive upper class over the boards of major cultural institutions (DiMaggio $1982 a, 1982 b)$. Thus, as early as the 1880s the Boston elite had established an art museum (the Boston Museum of Fine Arts) and an orchestra (the Boston Symphony Orchestra) that enabled them to maintain a distinctive cultural style. Boston's cohesive and highly educated upper class, however, was fairly unusual in that period (e.g., Jaher 1982). It contrasted most remarkably with the New York elite, which in the wake of the Civil War had been more permeable to emerging industrial entrepreneurs, and where old merchant families whose prestige rested primarily on ancestry were increasingly threatened by the clout - and fortunes - of newly moneyed capitalists (Jaher 1972, 1982; Hammack 1982; Beisel 1990, 1997; Beckert 2000).

Scholars have argued that the divided nature of elites in New York delayed the establishment of a coherent corpus of high culture and thereby the emergence of cultural capital as a source of status for the city's elite (DiMaggio 1987, 1991; Dowd et al. 2002; Benzecry 2014). In the case of music, for example, DiMaggio notes that in New York "shifting coalitions within [a] fragmented elite created numerous orchestras, none of them suf-

\footnotetext{
${ }^{4}$ This is an analytically different issue from understanding how culture reinforces the elite by unifying it around a set of shared practices, as illustrated by Beckert (2000) in his history of bourgeoisie formation in Gilded Age New York. High-culture venues here work alongside elite social clubs, select schools, and marriage alliances to generate the social networks that ultimately transform those who share a privileged position into a social class with a sense of its collective interests (e.g., DiMaggio 1987; Ostrower 1998; Lizardo 2006).
} 
ficiently successful to define a single canon of fine-arts music. Competing orchestras sought public favor through public differentiation, light programming, novelties, and extravaganzas long after Boston's symphonic repertoire had become limited and austere" (1991, p. 136; see also Mueller 1951).

While we agree that the lack of cohesion of New York's upper class hindered the emergence of cultural capital through elite-driven processes of purification and closure, in the analysis to follow we find that purification still happened in New York. We further argue that the city illustrates a different mechanism that helped to turn elite culture into a form of socially valuable capital. Specifically, we show that one of the foremost elite cultural institutions in the city increasingly included an emerging, educated middle class among its audience members. Understanding that dimension of the constitution of cultural capital matters not only because of New York's subsequent role as a dominant cultural center in the country. It is also analytically important, as it factors in the evolution of the United States toward a more socially differentiated and modern society. ${ }^{5}$

Social Differentiation, Cultural Legitimacy, and the Segregated Inclusion of an Educated Middle Class

Transformations of U.S. society in the Gilded Age went beyond mass migration, the rise of an American working class, and the emergence of powerful corporate interests. They also involved an increased differentiation of American society. The deepening of the division of labor meant that the economy pulled away from the household and the local community (Wiebe 1967; Bender 1978); that new spheres of activity — such as politics or the professions (Dawley 2005) — emerged around new areas of expertise; and that the day-to-day management of sprawling corporations was no longer assumed directly by entrepreneurs and industrialists (Chandler 1977).

This growing differentiation entailed the rise of an educated middle class of professional and intellectual individuals who were neither owners of economic capital nor the descendants of prestigious lineages, but who possessed expertise in specific domains (Gouldner 1979; Beckert 2000). This new group of professionals worked across the economy and in the natural, humanistic, and social sciences. Johnson and Powell (2017, p. 213) thus observe that, "in the early nineteenth century, the fields of law and medicine had seen an increase in expertise via the introduction of educational reforms, the establishment of board exams and licenses, and the diffusion

${ }^{5}$ The mechanism that we describe was likely at work in Boston too. As noted by DiMaggio (1982a, p. 40), "While we have all too little information about the nature of the visitors to Boston's Museum or of the audiences for the Symphony, it seems certain from contemporary accounts (and sheer arithmetic) that many of them were middle class." 
of local, state, and national professional associations." In the realm of business, too, by the 1870s transformations in the organization of knowledge had led to the emergence of "disciplinary specialists and professional managers to whose expertise Gilded Age industrialist-philanthropists deferred" (Johnson and Powell 2017, p. 200; on the professions, see Bledstein [1976]; Abbott [1988]; on science and social science, see Reingold [1976], Haskell [1977], Olenson and Voss [1979], and Sloan [1980]).

A key dimension of the constitution of high culture into a capital capable of sustaining the status of elites is that it be regarded positively by other social groups - in other words, that it be legitimate. As DiMaggio (1982a, p. 48) puts it, in the Gilded Age "a secret and esoteric culture could not have served to legitimate the status of American elites; it would be necessary to share it, at least partially." Striking the right balance between exclusivity and legitimation was at the core of efforts to transform elite culture into a form of socially valuable capital. Against this backdrop, the emergence of an educated middle class offered an obvious opportunity for elites' cultural enterprises. In New York in particular, where the upper class was generally less educated than it was in Boston, a professional, managerial, and intellectual group provided a natural audience with whom to share elite culture. In the analysis to follow, we show that at the New York Philharmonic elites were not driven away by the gradual inclusion of this emerging group. Quite to the contrary, they seemed to welcome an audience featuring more educated, middle-class individuals and minimizing "socially fashionable types." Thus, while Boston's cohesive and highly educated elite may make it the exemplary case of the formation of cultural capital through elite entrepreneurship and cultural purification, New York, with its fragmented and less dignified upper class, stresses how the constitution of high culture into a form of capital also rested on processes of cross-class inclusion.

Inclusion rarely appears in accounts of the constitution of cultural capital insisting on purification. These accounts typically relate the valorization of high culture to the correspondence between its content and the social standing of those who enjoyed it. While we concur that this is a key dimension of the emergence of cultural capital, we argue that the association of elite and nonelite groups in the consumption of high culture also contributed to that transformation.

At the New York Philharmonic this was facilitated by the stratified nature of the concert hall, which meant that the elite could continue to distinguish themselves by consuming music from seats that differed from those of other, newly included groups. This was particularly important at a time marked by the increasingly public character of cultural consumption (DiMaggio 1991). The evolution of sitting patterns in the hall, we argue, reflected the increased salience of a form of distinction centered less on the content of the culture elites consumed and more on the way they enjoyed it. More 
broadly, it is an example of what we refer to as segregated inclusion-a form of inclusion that comes with new ways for a dominant group to demarcate itself from newcomers, thereby preserving its purity and specialness.

Hence, in a differentiating society and in the absence of a strongly educated elite, cultural capital could be constituted through the inclusion of a rising professional, managerial, and intellectual group within elite-sponsored institutions. That process entailed new ways of consuming culture, with more subtle elements of distinction taking over-ultimately resulting in a form of segregated inclusion.

\section{GILDED AGE NEW YORK AND THE NEW YORK PHILHARMONIC}

In the final decades of the 19th century millions poured into lower Manhattan and Brooklyn, fundamentally transforming social and class relations in New York City. Most of these migrants were poor; many spoke different languages and had different religions. In response to the influx of workingclass immigrants, elites moved away from their homes in lower Manhattan to what is now Murray Hill, Midtown East, and, eventually, the Upper East Side.

The immigrant influx was not the only change to the class structure, however. At the top, too, New York society evolved toward something much more divided and diverse. As Hammack (1982, p. xv) describes, "Between 1880 and 1910 Greater New York became the first American metropolis to assume a modern character. Nineteenth-century New York had been a great mercantile center; by 1895 corporate managers were displacing merchants and the city's economy was demanding more specialists, more whitecollar workers, more semiskilled laborers. New York had always been remarkable for its social heterogeneity; by the 1890s its Anglo-Protestant social elite was both internally divided and challenged by competing German Christian and German Jewish social elites."

Culture helped the elite address the twin challenges of a growing working class and a fragmenting upper class. By making the content and places of their cultural activities distinct from those of working-class groups, elites gradually built a "class-segmented public sphere" (Beckert 2000, p. 267) and added a layer of cultural distance to the geographic distance they were achieving by moving uptown. In part this meant founding or sponsoring a

\footnotetext{
${ }^{6}$ Hammack further emphasizes the continual differentiation of these groups: "By the 1890s New York City's lawyers as a group were losing the near-monopoly over municipal expertise they had so long enjoyed.... In the last decade of the century, lawyers were further crowded aside by graduates of the new university programs in public law and administration, economics, social welfare, and education who were taking positions in the city's universities, welfare agencies, and editorial boards and developing their own policy ideas there" (1982, p. 54).
} 
set of high-culture institutions such as the Metropolitan Museum of Art, the Metropolitan Opera, the New York Symphony, and the New York Philharmonic (Kolodin 1966; Shanet 1975; Cone 1983; Martin 1983; Eisler 1984; Tomkins 1989). These institutions also contributed to clarifying what elite tastes were and thus helped to consolidate the fractured upper class around shared understandings, shared practices, and shared experiences. As Beckert argues, "Cultural identifications would increasingly provide the glue that kept an expanded bourgeoisie together" (2000, p. 254).

Rivalries within the elite, on the other hand, impeded alliances behind a single institution in each cultural field. In the realm of music, for example, competing factions divided their support between such organizations as the New York Philharmonic and the New York Symphony (Mueller 1951; Dowd et al. 2002). Diluted patronage prevented any particular faction from wresting control from the orchestras' commercial entrepreneurs, and this in turn made it difficult to impose a clear set of canonical standards through mere elite entrepreneurship (DiMaggio 1991).

The New York Philharmonic was emblematic of that situation. Founded in 1842, it is one of the oldest symphonic orchestras in the world, and it has long been a beacon of American cultural life. ${ }^{7}$ The orchestra was initially a musicians' cooperative, with players owning shares and splitting the proceeds from ticket sales. Members appointed a board of directors (almost exclusively musicians at first) who managed the operations of the cooperative. Demographically, the orchestra was overwhelmingly German. At its first concert in 1842, $42 \%$ of the orchestra's members were ethnically German, and by 1855 this number had risen to an astonishing $79 \%$ (Shanet 1975 , p. 109). The audience, on the other hand, was made up of New York's "good" society. By the orchestra's second season George Templeton Stronga famed diarist and then a 23-year-old music enthusiast - noted a "great crowd: all the aristocracy and 'gig respectability' and wealth and beauty and fashion of the city there on the spot an hour beforehand" (cited in Shanet [1975], p. 99). Those elite New Yorkers included men whose names would be imprinted on the city of New York: William B. Astor, Henry Brevoort, Goold Hoyt, or Peter Schermerhorn.

The Philharmonic Society struggled for space in New York's crowded orchestral field. In its early years it competed with conductor Theodore Thomas, whose Theodore Thomas Orchestra was enormously popular among New Yorkers (Russell 1927). The Philharmonic eventually dealt with this competition by hiring Thomas to replace its conductor Leopold

\footnotetext{
${ }^{7}$ Shanet's (1975) Philharmonic: A History of New York's Orchestra provides a thorough overview of the institution from its founding to the early 1970s. Scholarly readers will find far more relevant Mauskapf's (2012) organizational analysis in "Enduring Crisis, Ensuring Survival: Artistry, Economics, and the American Symphony Orchestra."
} 
Damrosch in 1877 - only to see Damrosch create a rival orchestra, the New York Symphony, one year later (the two orchestras would merge in 1928). Intracity competition was not the only challenge. Soon after its founding in 1881, the Boston Symphony Orchestra started traveling regularly to New York to give concerts, and audiences tended to prefer its quality over that of any local orchestra.

In that environment the Philharmonic needed to satisfy the demands of its wealthy patrons lest they abandon it for other institutions (Shanet 1975; Mauskapf 2012). Through their role as benefactors, between 1860 and 1910 elites slowly gained de facto control over the cooperative and its artistic direction. After 1867 the orchestra's president would never be a musician again. Andrew Carnegie assumed that role in 1902, and in 1909 Mary Sheldon was finally successful at transforming a failing players' cooperative into a nonprofit enterprise employing salaried musicians and governed by a board of wealthy philanthropists. ${ }^{8}$

Long before that shift, however, the content of culture at the Philharmonic had evolved toward greater purity, despite the lack of strong cultural entrepreneurship by a cohesive and highly educated elite (Block 2012). Here we provide evidence of that purification by looking at the evolution of the orchestra's repertoire over the period. Whether a choice of conductors and musicians themselves, a reflection of elites' growing influence, or a response to the programming of rival institutions, in the 1860s and 1870s the Philharmonic gradually turned into a sanctuary for the music of a small number of consecrated composers. ${ }^{9}$ By 1892 , music critic Henry Krehbiel described a repertoire of purified, great works:

If I were to attempt an interpretation of the record I should say that [the orchestra] has conceived its duty primarily to be the conservation of musical compositions which the judgment and taste of the cultured would have admitted of the first rank. Only secondarily has it made propaganda for new and progressive composers who have widened the boundaries of the art. . . The [Philhar-

\footnotetext{
${ }^{8}$ The transformation was facilitated by a large gift from Joseph Pulitzer, who donated $\$ 500,000$ to the orchestra in his will, and another half million on the condition that the Philharmonic change its organizational model (these gifts were delivered in 1912). Sheldon was also instrumental in hiring prestigious conductor Gustav Mahler to lead the orchestra in 1909.

${ }^{9}$ The conductor of the Philharmonic in the late 1870s and 1880s, Theodore Thomas, explicitly decided to limit his repertoire and was celebrated for it. He noted in an interview in 1882 that he wished to perform "only standard works, both of the new and old masters, and to be thus conservative and not given to experimenting with the new musical sensations of the hour" (quoted in Shanet [1975, p. 167]). On the broader historical shift of Western orchestras in that period away from the programming of miscellany and toward a focused and finite canon, see Burkholder (1986) and Weber (2001); on the role of conductors in channeling that shift, see Dowd et al. (2002), Kremp (2010), and Santoro (2010).
} 


\section{American Journal of Sociology}

monic] Society is also enjoined to exercise the greatest care in the admission of new compositions into its lists. A work that has been played at a Philharmonic concert is, by virtue of that circumstance, looked upon as bearing the most valid stamp of excellence which the New World can bestow. (Krehbiel 1892, p. 9)

A systematic look at what was played at the Philharmonic confirms that movement toward purification. The full record of programs, available from the Philharmonic archive, makes it possible to compute the number of unique composers played every season between the 1850 s and the early 20th century. Figure 1 displays the evolution of that number, adjusted for the changing number of concerts in a musical season. In the mid-19th century, audience members could expect to hear the work of up to 30 different composers played in a single season. In fact, Philharmonic musicians did not hesitate to program music they had composed themselves, as well as pieces by contemporary American composers. By 1880, however, the number of unique composers programmed in a season declined by half to about 15, where it roughly remained through the rest of the Gilded Age. The Philharmonic increasingly focused on a small range of canonical composers, most of them German, and most of them dead.

A second, more subtle indicator of the purification of the repertoire can be found in the way programs were organized and musical pieces were ac-

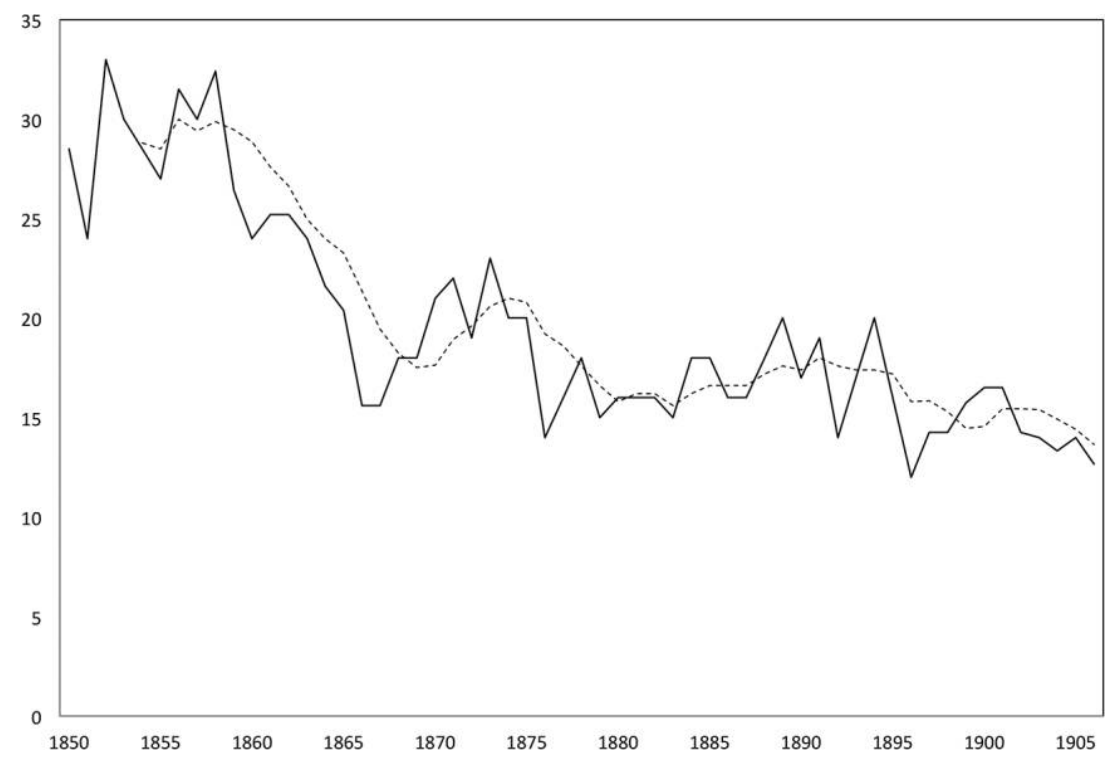

FIG. 1.-Number of unique composers played in a season, adjusted for number of programs, seasons $1850-51$ to $1906-7$ (dotted line: five-year moving average). 
tually performed. Figure 2 shows the average number of pieces in one night's program. That number decreased sharply through the mid-1880s, dropping from around seven to around four pieces a concert. Less diverse programs not only meant that each concert was now more focused on a few, carefully chosen musical works. It also made it possible to perform pieces that were played in their entirety. Thus, while early on only about $40 \%$ of the music given by the orchestra consisted of full pieces - the rest being made of a miscellanea of excerpts such as famous opera arias or single movements taken from symphonies - that percentage gradually rose to about $70 \%$ in the 1880 s (fig. 3). The repertoire, in other words, was not just purified from the music of composers deemed unworthy of its stamp of excellence. The music itself also achieved greater sacredness, as it became increasingly unlikely that the orchestra would disregard the composer's complete vision by cutting his work to feature only popular excerpts.

The evolution of music at the Philharmonic in the second half of the 19 th century seems to support previous findings of purification and sacralization. A closer look at the timing of that evolution, however, complicates the picture. The bulk of the purification occurred between in the 1860s and 1870s. The three indicators we introduced - number of composers in a season, number of pieces on an average night, and percentage of full pieces - all display sharp changes until 1880 yet remain stable through the 1900s. The consoli-

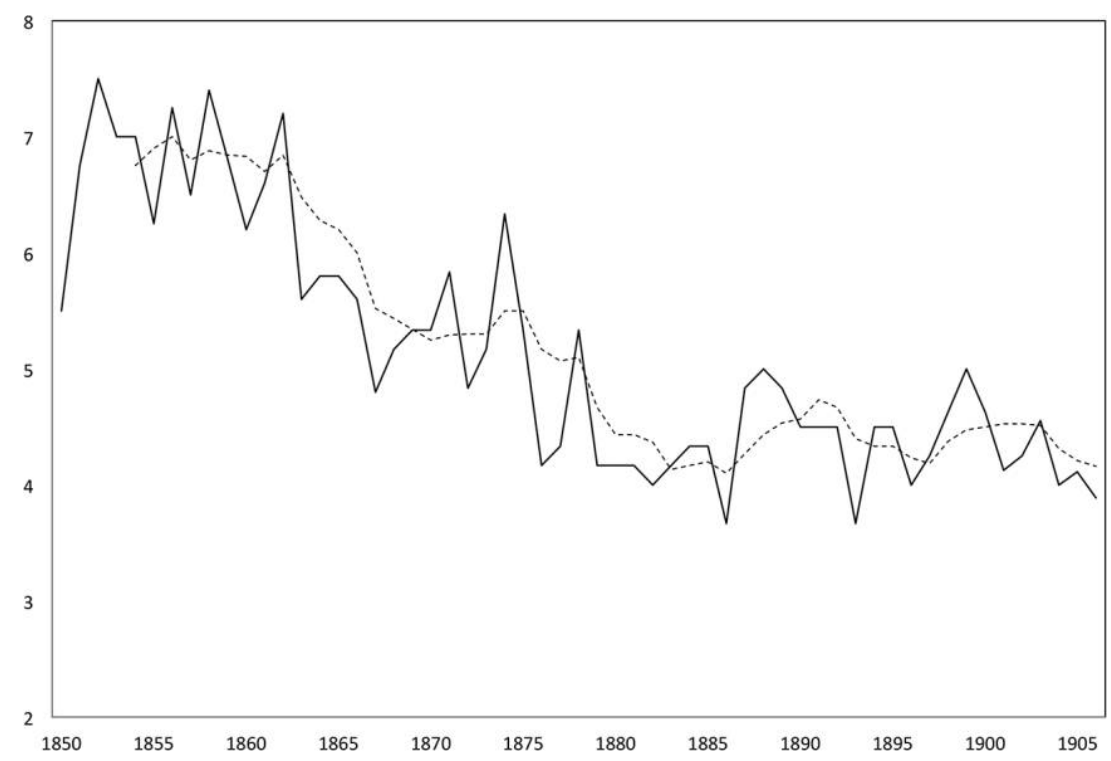

FIG. 2.-Average number of pieces per program, seasons 1850-51 to 1906-7 (dotted line: five-year moving average). 


\section{American Journal of Sociology}

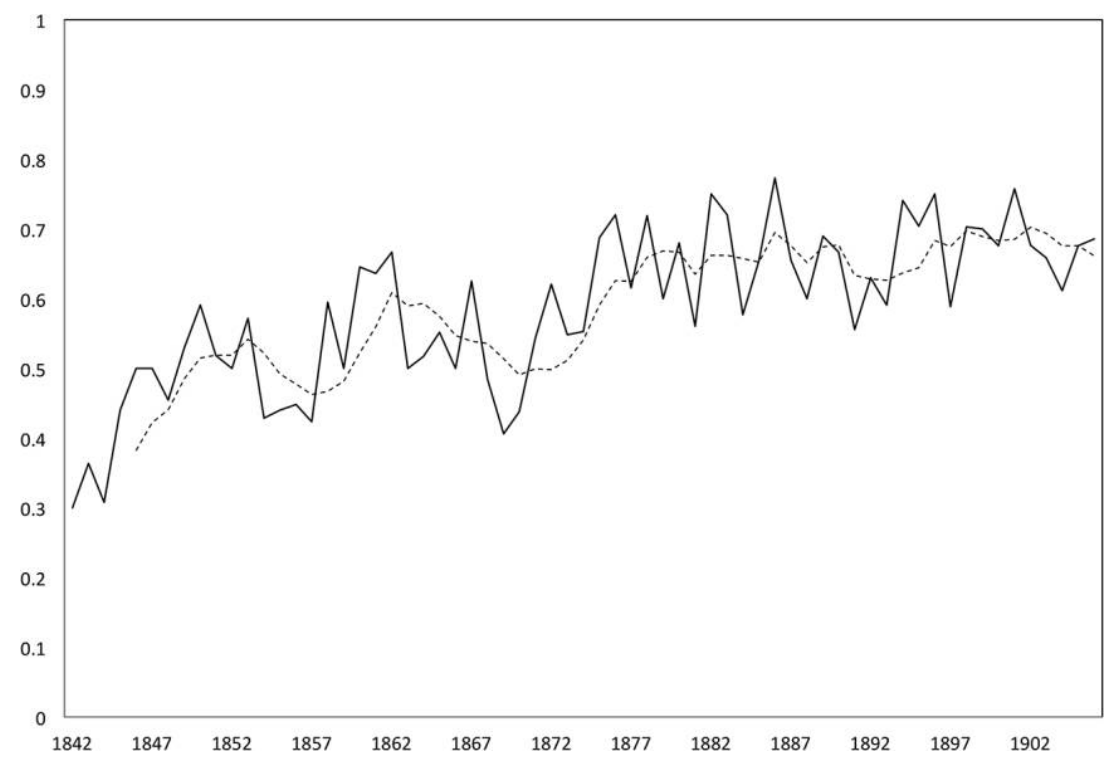

FIG. 3.-Proportion of full pieces in a season's program, seasons 1842-43 to 1906-7 (dotted line: five-year moving average).

dation of high culture at the Philharmonic, in other words, happened long before elites had gained full control of the institution. While we cannot adjudicate how this happened, we observe that culture could purify in the absence of strong cultural entrepreneurship by a cohesive and educated elite.

In the remainder of this analysis we turn away from what was happening on the stage to study the Philharmonic audience in the period that immediately followed this purification of the repertoire. We show that attending the orchestra remained an elite practice after 1880. Yet we also find that the audience kept evolving significantly well after the music had been purified. Because changes in the music provide limited insight into audience dynamics, we rely on data that directly record who attended the Philharmonic in the late Gilded Age. We use these data both for descriptive ends and to refine our understanding of how high culture was constituted as cultural capital in late 19th-century New York. ${ }^{10}$

${ }^{10}$ Not only is who attended these concerts of interest to the authors of this article; it was a matter of public scrutiny and reporting. Most New York Times reviews during that era commented on the audience. The New York Times report of April 15, 1882, thus noted, "The audience yesterday afternoon was one of the best and most intelligent that has appeared at any concert or rehearsal of the society." Decade by decade this continued: "Today the Philharmonic audience represents, nay more, it actually is, the genuine musical public of New York" (April 25, 1892); "[The Philharmonic] is still the highest musical court in New York, and its Saturday night audiences are the flower of the refinement 
Cultural Capital

DATA

\section{Primary Data Sources}

To understand how the structure of high-culture participation evolved at the New York Philharmonic, we draw on complete subscription records for all Philharmonic subscribers from the late 1880s to the late 1900s. The primary data are contained in the orchestra's subscriber and seating books, which respectively report the names and addresses of subscribers and the names of the tenants of each subscribed seat.

As part of a collaborative project with the Philharmonic we compiled a data set of all subscribers to the orchestra, in all seasons wherein subscriber and seating books were available between the founding of the Philharmonic in 1842 and the present day. ${ }^{11}$ For all subscribers we recorded the address they reported to the Philharmonic, the number of seats they held, and the location of these seats in the concert hall. Over the period this article focuses on, a Philharmonic season included between six and eight different programs. Each program was given twice, as a public rehearsal on Friday afternoon and as the actual concert on Saturday night. Both the rehearsal series and the concert series were open to subscription, and we have information on subscribers to both.

It is important to note that we do not have data on all attendees to Philharmonic performances. Our information is restricted to those who subscribed to entire seasons of the orchestra's concerts and therefore ignores single-ticket holders. We believe that these data are relevant nonetheless, as subscribers were those who had not only an interest in the music but also a symbolic commitment to the orchestra itself, making them a meaningful group to look at. While the Philharmonic archive does not retain information on the number of single tickets sold for each concert, we know that subscribed seats accounted for about $27 \%$ of the seats in the hall in 1889-90 and $43 \%$ in both $1897-98$ and $1906-7$.

\section{Historical Focus and Contextual Data}

In order to contextualize subscribers within the broader social life of the city, we selected three specific seasons, roughly nine seasons apart, to focus on in

and culture in the city.... Approbation from this audience is applause indeed" (April 6, 1902).

11 "Subscribers to the New York Philharmonic, 1842-Present," supported by the Andrew W. Mellon Foundation Scholarly Communications program (grant no. 31200640). While subscriber and seating information was available for almost every season after 1950, there are significant gaps in the data in earlier periods. Thus the Philharmonic archive does not retain any substantial data on subscribers prior to season 1882-83 and between seasons 1906-7 and 1950-51. Our subscriber data are available for download at the Philharmonic website: http://archives.nyphil.org. 
greater detail: 1889-90, 1897-98, and 1906-7. These seasons span the period we are interested in. They are also among the ones for which we have complete Philharmonic information. We have no reason to believe that the completeness of the data in these years relates to the explanations that we provide. Importantly for our argument, prices and pricing schemes for season tickets did not evolve significantly over these three years: prices increased by about $20 \%$ in all sections of the Philharmonic's hall between our first two seasons and then remained constant through the third.

There were 918 unique subscribers to the Philharmonic in 1889-90, 1,323 in 1897-98, and 1,297 in 1906-7. In any of these years a recorded subscriber could hold more than one seat and on average held around two. ${ }^{12}$ While we can expect that subscribers generally attended the concerts they subscribed to, we do not know who occupied the additional seats that they held. As the vast majority of subscribers were married women, however, we can reasonably assume that a number of these extra seats were held by their husbands or children. In line with this interpretation the analyses presented in this article are conducted at the family level, and we treat married subscribers as representing their larger household in the halls of the Philharmonic.

With our three focal years in mind, we collected supplemental materials to contextualize subscribers within the population of New York and within the city's upper class in particular. We use the New York Social Register, a directory of predominantly white Anglo-Saxon Protestant families, as an index of the city's social elite (Higley 1995). The Social Register was created in New York in 1886, initially as a compilation of old elite families. By 1889 it had grown into a full-fledged directory of New York "good" society, listing around 12,000 prominent families, or $1 \%$ of the city's population. In order to be included in the Social Register one had to either be born to listed parents, marry a listed member, or be proposed and supported by letters from current members, before being voted on by an advisory board. Marrying inappropriately, being subject to a scandal, or considerable downward mobility could be grounds for exclusion. Colloquially, the register was referred to as the "stud book," used as a way to identify men eligible for marriage from "good" families. ${ }^{13}$ For every subscriber to the Philharmonic we checked if he or she was listed in the Social Register. When subscribers were married women we reported the details of their husbands, essentially using men's

\footnotetext{
${ }^{12}$ Specifically, each recorded subscriber held an average of 2.1 seats. That average remains constant over our three years of interest, as does the variance in the number of seats held by recorded subscribers. Every year a small proportion of subscribers (about 4\%) held seats for both the rehearsal and the concert series. They may have attended both or subscribed on behalf of someone else for one of the series.

${ }^{13}$ This is why we prefer the Social Register to Who's Who in America. Who's Who is based on meritocratic selection criteria that make it less representative of the social elite.
} 
status as a proxy for that of their household. We also collected a $10 \%$ sample of the Social Register for 1889, 1897, and 1906. This sample reports the names, addresses, alma maters, and club affiliations of about 1,800 individuals in each of the three years.

Occupational data taken from the census are relatively sparse in this period. We therefore used additional sources to gather information on the occupations of Philharmonic subscribers. The first-Club Men of New Yorkis a registry based on the full membership lists of about 100 clubs located in and around New York City. It was published three times, in 1892, 1897, and 1902. Besides addresses and club affiliations, it reports the occupation of the individuals it lists as club members. Using the website Ancestry.com, we also garnered occupational information from other administrative and business archives, such as city directories. Through a careful combing of $C l u b$ Men and a systematic search of the census and Ancestry, we were able to retrieve occupational data on about $52 \%$ of subscribers in $1889,50 \%$ in 1897 , and $43 \%$ in $1906 .{ }^{14}$

Finally, we augment our quantitative data with the commentary of contemporary cultural critics. We draw on the writings of the dominant cultural newspaper of the day, the New York Times. We read every article published in the Times pertaining to the Philharmonic from the period of 1870-1910. To verify that the Times reporting was representative we also read the reviews of the Nation and the Tribune of every classical concert during this same period.

We begin our analysis by sketching the changing participation of New York's social elite to the Philharmonic over the final decades of the Gilded Age. We then turn to other social groups to show that the Philharmonic became more inclusive over time, and we describe newly included audiences in greater detail. Finally, we use seating data to analyze patterns of attendance and to ask how the location of various groups in the space of the concert hall related to their broader position in the city's social landscape. We show that these changes are consistent with a specific pathway toward the constitution of elite culture into cultural capital, marked by the segregated inclusion of an educated middle class whose presence could help to signal the worth of elites' cultural endeavors.

\footnotetext{
${ }^{14}$ The drop in the final year likely arises from a greater temporal mismatch between our year of interest at the Philharmonic (1906-7) and the edition of Club Men we compared it to (1902). Because part of our information comes from Club Men and clubs were often elite pastimes, the social elite may be overrepresented in the group for which we have occupational information. Club Men, however, lists a large number of individuals who belonged to various clubs but were not part of the social elite - as defined by inclusion in the Social Register. An analysis of the home addresses of a sample of individuals listed in Club Men shows that their residential backgrounds differed quite sharply from those of the social elite and matched those of the general New York population better.
} 


\section{ENDURING DISTINCTIVENESS: THE SOCIAL ELITE AT THE PHILHARMONIC}

Throughout the end of the Gilded Age attendance of New York Philharmonic concerts was and remained a distinctive elite practice. To approach the participation of the social elite we first focus on individuals listed in the New York Social Register. Table 1 presents the proportion of Philharmonic subscribers who were listed in the register in, respectively, 1889, 1897, and 1906. That proportion was fairly high throughout the period: though the register listed only around $1 \%$ of the population of the city in those years, about one in five Philharmonic subscribers were part of it. What is more, while the number of subscribers increased over time, the number of subscribers featured in the Social Register rose at a faster pace, bringing the proportion of subscribers in the register from $15.7 \%$ in 1889 to $19.8 \%$ in 1897 and $21.3 \%$ in $1906 .^{15}$

That Philharmonic attendance remained an elite practice is further suggested by the geographic spread of subscribers in the city, as displayed in figure 4, which focuses on the borough of Manhattan. ${ }^{16}$ Throughout the late Gilded Age subscribers' homes clustered in the city's most prestigious and less populated areas, such as the administrative wards that contained sections of Fifth Avenue on the East and Upper East Sides of Manhattan. An even more striking view is provided by a look at subscriber ratesthe proportion of subscribers in an area's population - at the tract level in 1906 (fig. 5). We here extrapolate tract-level population information in 1906 from the 1910 population census, as the tract system replaced the rougher-grained ward system at that later date only. Tracts with the highest rates of Philharmonic subscriptions in 1906 clustered around Fifth Avenue, where as much as $3 \%$ of the population of certain tracts could be subscribers. If one keeps in mind that an average subscriber subscribed to two seats, this means that $6 \%$ of the people living in these tracts held seats to the Philharmonic on a given evening (assuming that subscribers were going with family members).

The turnover of subscribers with various social backgrounds from one season to the next comes as a third piece of evidence for the enduring special

${ }^{15}$ The percentage of Social Register families that held at least one subscription to the Philharmonic remained around $1.4 \%$ from 1889 to 1897 and then declined slightly, to $1.1 \%$ in 1906 . The late decline reflects a growth in the Social Register population unmatched by a rise in the numbers of Social Register subscribers. The growth of the Social Register was even steeper between 1889 and 1897, but it was matched by an equivalent influx of Social Register subscribers.

${ }^{16}$ Manhattan supplied the bulk of Philharmonic subscribers, though it is difficult to establish an exact proportion. Some subscribers who lived in Manhattan for most of the year provided the Philharmonic with the addresses of only their summer homes out of the city. Of subscribers who reported an address in one of the five New York City boroughs, 99\% came from Manhattan in 1889, 98\% in 1897, and 96\% in 1906. 
TABLE 1

New York Philharmonic Subscribers in the Social Register

\begin{tabular}{|c|c|c|c|}
\hline & $\begin{array}{l}\text { 1889-90 } \\
\text { Season }\end{array}$ & $\begin{array}{l}1897-98 \\
\text { Season }\end{array}$ & $\begin{array}{l}1906-7 \\
\text { Season }\end{array}$ \\
\hline \multicolumn{4}{|l|}{$\%$ subscribers listed in the } \\
\hline New York Social Register . . . . . . . & 15.7 & 19.8 & 21.3 \\
\hline $\begin{array}{l}\% \text { Social Register listees subscribing to } \\
\text { the New York Philharmonic } \ldots \ldots \ldots \ldots\end{array}$ & 1.4 & 1.4 & 1.1 \\
\hline Total number of subscribers. . . . . . . . . & 918 & 1,323 & 1,297 \\
\hline
\end{tabular}

relationship of the social elite with the Philharmonic. Throughout the late Gilded Age subscribers listed in the Social Register were more likely to renew their commitment to the orchestra over successive musical seasons. They formed a core of stable, dedicated patrons. Table 2 displays the Philharmonic's retention rates of subscribers between seasons 1889-90 and 1897-98, broken down by subscribers' social background. It shows that $20 \%$ of 1889 subscribers without a social elite background - as approached through membership in the Social Register-remained subscribers in 1897. Over the same time window social elite subscribers were more than twice as likely to stick with the Philharmonic: $45 \%$ of 1889 subscribers listed in the Social Register held a subscription to the orchestra in 1897. If anything, this difference in long-term commitment across social groups grew wider in the following decade, suggesting that the social elite did not loosen its grip over the institution. While only $12 \%$ of non-social elite subscribers in 1897 remained subscribers in 1906, social elite subscribers were now almost three times as likely to stay: 30\% of those who held seats in 1897 still did in 1906 . The overall decline in retention rates from one time window to the next likely arises from the mere difference in the length of these windows (eight to nine seasons), as well as from the organizational and artistic turmoil at the Philharmonic in the early 1900s. Yet the growing gap in retention rates between social elite and non-social elite subscribers is the pattern we would expect if the social elite increasingly distinguished itself from other social groups through its sustained participation in high culture.

\section{Changing Patterns of Elite Participation}

Focusing on social elite members who subscribed to the Philharmonic shows not only that socially elite members were more likely to attend concerts but also that the very way subscribers attended the orchestra's concerts evolved toward greater stratification around the turn of the century. Not all seats were equally desirable. Seats in first- and second-tier boxes were more desirable that those in the parquet, which was more desirable 

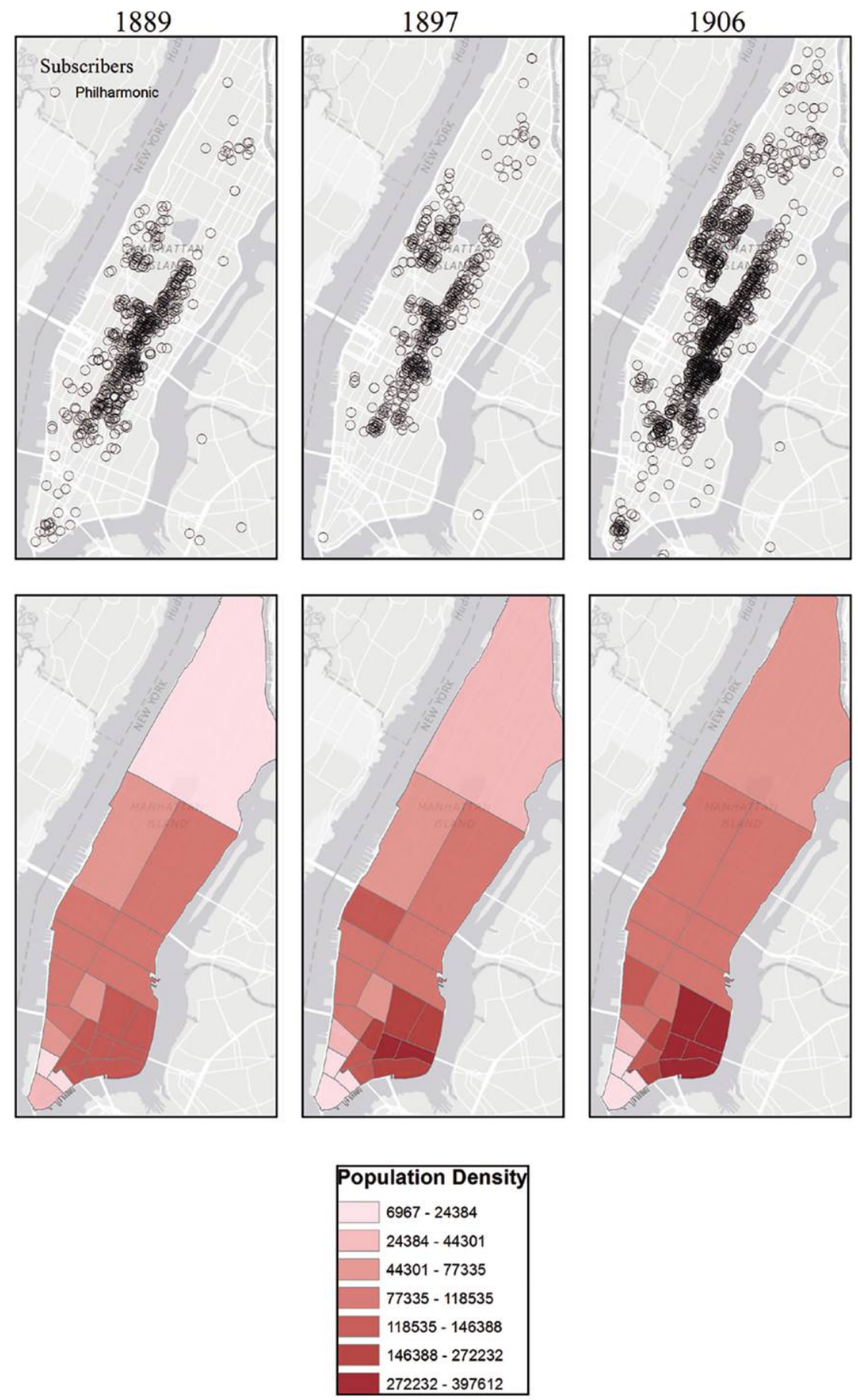

FIG. 4.-Philharmonic subscribers in Manhattan and population density by Manhattan ward, 1889-90, 1897-98, and 1906-7 (densities, in population per square mile, are calculated using a linear extrapolation of each ward's population based on census data in 1890,1900 , and 1910). 


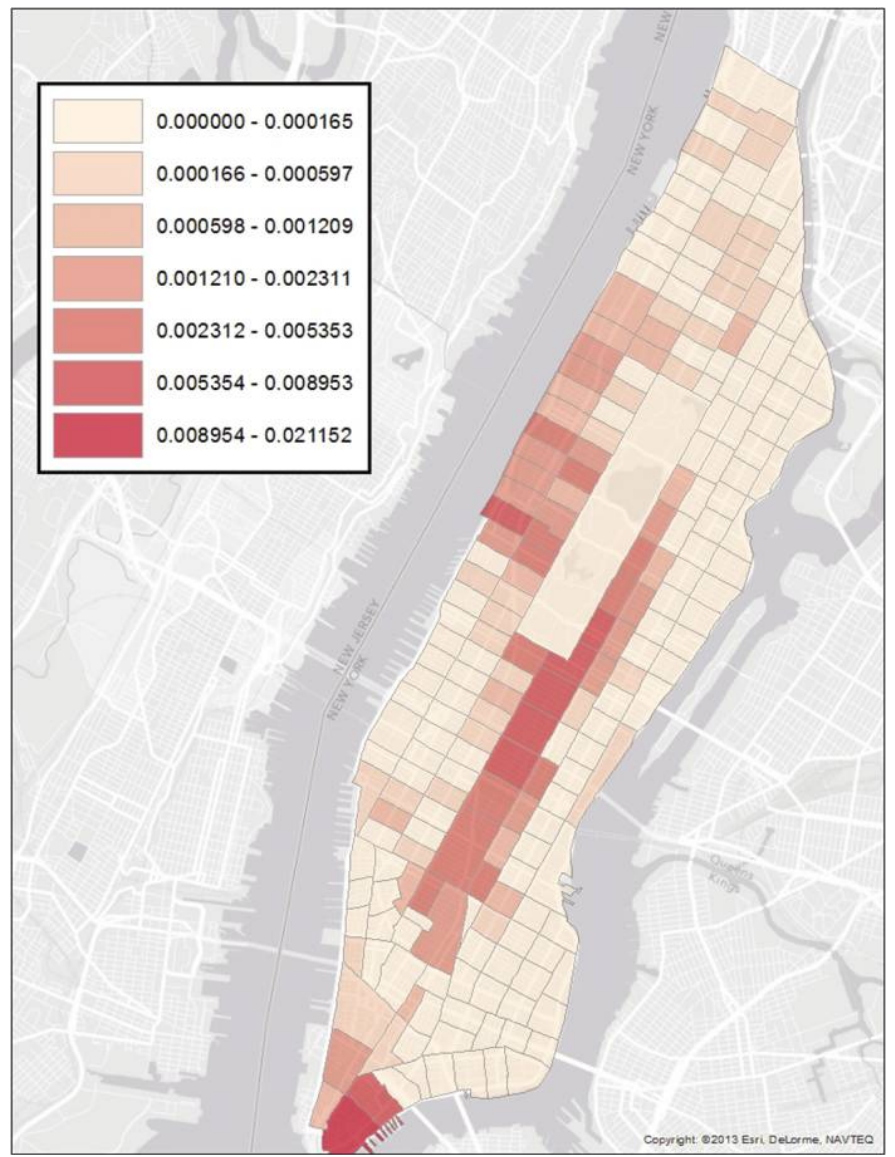

FIG. 5.- Philharmonic subscription rates by Manhattan census tract, 1906-7 (rates are calculated using a linear extrapolation of each tract's population based on tract-level data in 1910 and ward-level data in 1900).

than the dress circle; and balcony seats were the least desirable of all-a hierarchy that was reflected in the seat pricing scheme. ${ }^{17}$ Even though that scheme remained unchanged over the period, figure 6 shows a strong pattern in the evolution of the proportion of subscribed seats held by the socially elite in various sections. Throughout, seats located in better sections were more likely to be subscribed by patrons listed in the Social Register.

${ }^{17}$ While the Philharmonic moved halls in 1892, the seating charts of the old Met House and the new Carnegie Hall had comparable structures. The old Met had a larger seating capacity, however. It could fit an audience of about 3,600, against only around 3,200 at Carnegie Hall. 


\section{American Journal of Sociology}

TABLE 2

Retention Rates of Subscribers from Various Social Backgrounds

\begin{tabular}{lcc}
\hline \hline & $\begin{array}{c}\text { Social Elite } \\
\text { Subscribers }\end{array}$ & $\begin{array}{c}\text { Other } \\
\text { Subscribers }\end{array}$ \\
\hline \% back from 1889-90 to $1897-98 \ldots \ldots \ldots$ & 45.4 & 20.2 \\
\% back from 1897-98 to $1906-7 \ldots \ldots \ldots$ & 30.4 & 11.7 \\
\hline
\end{tabular}

Note.-Formula for two time periods $\left(\chi_{1889-90 \text { to } 1897-98}^{2}=40.7, p<.0001 ; \chi_{1897-98 \text { to } 1906-7}^{2}=53.3\right.$, $p<.0001)$

But while only about $40 \%$ of first-tier boxes were held by members of the social elite in 1889 , one in two were in 1897 , and almost $70 \%$ in 1906 . A smaller uptick is observed in other good areas of the hall (second-tier boxes and parquet). Less desirable sections (dress circle and balcony) in contrast experience a drop in their proportion of social elite subscribers. Over time the socially elite can be seen as having increasingly used the orchestra as a means of distinction not only by going more but also by going in more distinctive ways, deserting less desirable seats and concentrating in first- or second-tier boxes.

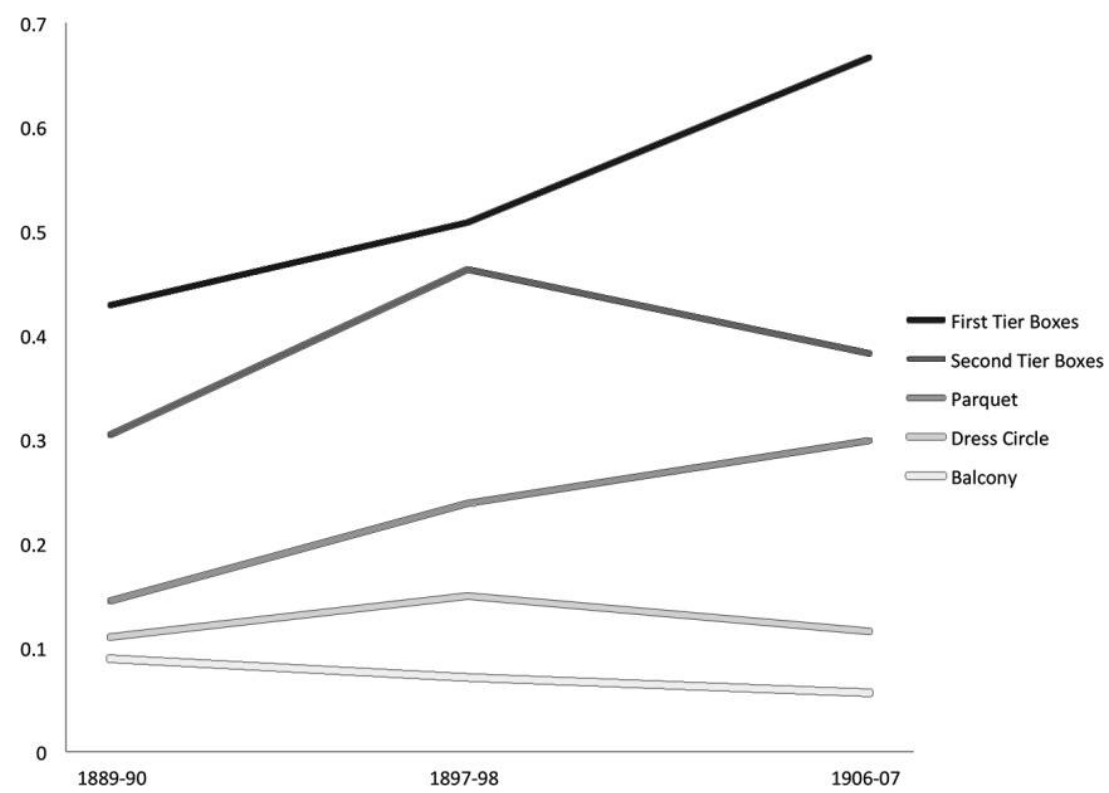

FIG. 6.-Proportion of subscribed seats held by Social Register listees, broken down by seating section.

1764 


\section{Cultural Capital}

Within the social elite itself, the status of subscribers also became increasingly predictive of the quality of their concert seats. To capture prominence within the elite we use the number of club affiliations individuals reported in the Social Register-now focusing on Social Register listees who were also Philharmonic subscribers. We then examine this measure's correlation with a subscriber's seat quality, rated on a scale of one to five, where one stands for a seat in the balcony and five for a seat in a first-tier box. If a subscriber held multiple seats in various sections, we measure the quality of the best of her seats. We report the results in figure 7. In 1889 a subscriber's number of club affiliations was not statistically associated with the position of her seats in the concert hall. Prominence in the social elite in contrast is significantly correlated with seat quality in 1897 (Spearman's rank correlation between the two variables is around .33). And the magnitude of the relationship is even larger - at around .39-in 1906.

For subscribers with social elite backgrounds, prominence in the elite was thus increasingly associated with sitting in more desirable areas, so that by the end of the Gilded Age sitting patterns did not record only differences

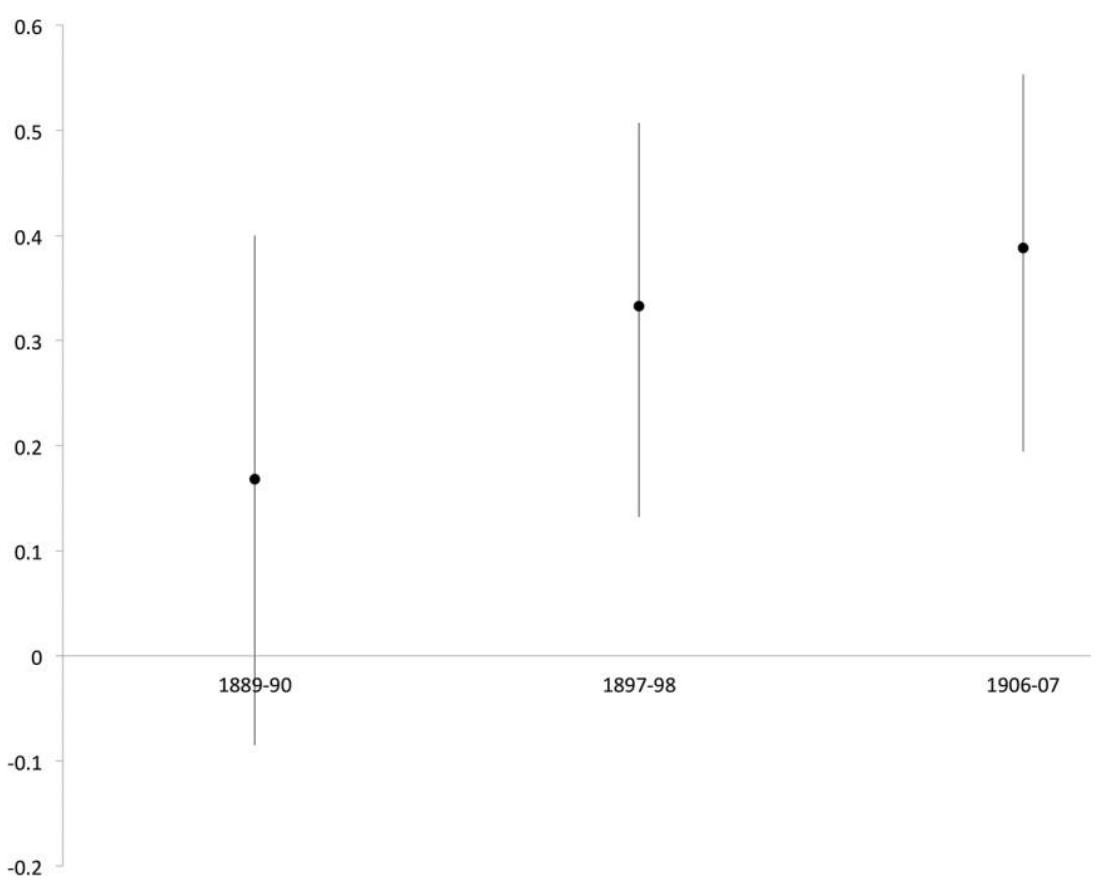

FIG. 7.-Spearman's rank correlation between the number of club affiliations and the seat quality of social elite subscribers. 
between the elite and the rest. In fractal fashion, hierarchy within the elite itself was also reflected in the hall, in the way more or less prominent elite members occupied the seats of various sections. This evolution at the finegrained level of seats held by subscribers buttresses the notion that participation in high culture increasingly served social distinction purposes. In the late Gilded Age, attending the orchestra was not only a way for the social elite to distance itself from other groups in the city. Holding specific seats in the concert hall also became a means for the most prestigious members of the social elite to draw even subtler boundaries between themselves and less prominent counterparts who also attended the orchestra's performances. ${ }^{18}$

The enduring distinctiveness of the Philharmonic was not lost on the commentators of the day. In their eyes the audience's overall command of high culture contributed to attendees' social value. In "The Philharmonic Audience" on April 25, 1892, the Times's lead music critic noted, "to the glory of music it can be said that the Philharmonic audience represents an element of the highest general culture in the city. It is composed of persons whose knowledge of what is excellent extends to literature, to fine arts, and to drama, whose social character and refinement are beyond a moment's question."

This view of a correspondence between a refined repertoire and the social standing of those who enjoyed it mirrors the idea that the content of culture is at the root of its social value. Indeed, from reports like this we can see why historians and sociologists identified the distinction of high culture as one of the conditions of its transformation into cultural capital during the Gilded Age. Focusing on the social elite and its relationship to high culture, however, obscures what else was going on in the hall in that period. A greater distinctiveness of elite culture did not have to happen at the expense of other groups' cultural participation. Our next section examines who else attended Philharmonic performances and how this supports the notion that, in New York, elite culture was constituted as cultural capital through a process of cross-class inclusion.

\footnotetext{
${ }^{18}$ Not surprisingly, the changing relationship we report here occurs only for Saturday concerts. At the Philharmonic, Saturday night concerts always carried more prestige than did Friday afternoon rehearsals. Social elite subscribers were in particular always more likely than others to subscribe to Saturday over Friday performances. By this measure the relative prestige of concerts also increased over time. In $1889,36 \%$ of social elite subscribers and $34 \%$ of non-social elite ones chose concerts over rehearsals. By 1906, social elite subscribers were twice as likely to choose concerts over rehearsals, while the rest of subscribers divided about equally between the two. Logics of distinction through seat choices within the population of social elite subscribers thus became more salient at events whose prestige was itself increasing. At Friday performances, elite prominence was predictive of seat quality throughout the period, but the magnitude of the relationship decreased over time.
} 


\section{INCREASING INCLUSIVENESS: THE EMERGENCE OF A NEW AUDIENCE}

Looking at the spread of Philharmonic subscribers in the city shows that new subscribers gradually joined the orchestra's ranks even though they did not share the residential choices of more elite patrons. Figure 8 plots subscribers' home addresses, distinguishing between subscribers with and without a Social Register background.

Over time new areas in the city, most notably the northern part of the Upper West Side, Morningside Heights, and Harlem, started sending subscribers to the Philharmonic. These neighborhoods were typically not the dwelling areas of the social elite - as suggested by a map of the geographic clustering in Manhattan of our 10\% sample of the Social Register (fig. 9). Figure 8 shows that few subscribers from these areas were Social Register listees. ${ }^{19}$ We thus observe the emergence of a geographically clustered group that subscribed to the Philharmonic yet that departed from the more traditional elite as far as their residential choices were concerned.

Figure 10 supports that view by measuring the residential clustering of social elite and non-social elite subscribers. Clustering is here approached through the spatial autocorrelation of subscribers' Social Register representation with the Social Register representation of their 25 nearest subscriber neighbors in the city. ${ }^{20}$ As evidenced in the top panel, spatial autocorrelation rises significantly between 1889 and 1906, indicating that Philharmonic subscribers in and out of the social elite increasingly came from different areas in the city. The bottom panel, based on a local indicator of autocorrelation, or local Moran's I, decomposes the increase and shows that throughout the period residential clusters of social elite subscribers remained located on the East Side around Fifth Avenue, while clusters of non-social elite subscribers emerged in the Upper East, Upper West, and Harlem areas of Manhattan.

This new group of audience members did not just make different residential choices from the social elite. Their occupational backgrounds also departed significantly from those of Social Register subscribers. Throughout the late Gilded Age, the lion's share of subscribers belonged to occupational groups that owned economic capital or organized its flows. Almost half of the subscribers for whom we have occupational information were merchants, manufacturers, bankers, brokers, or corporate lawyers in 1889, and while that proportion declined, it was still around 40\% in 1906.

${ }^{19}$ The last names of these subscribers, together with their absence from the Social Register, suggest that they were not just scions of the social elite who had relocated to more affordable, uptown neighborhoods.

${ }^{20}$ Alternative definitions of neighborhoods yield similar findings. 

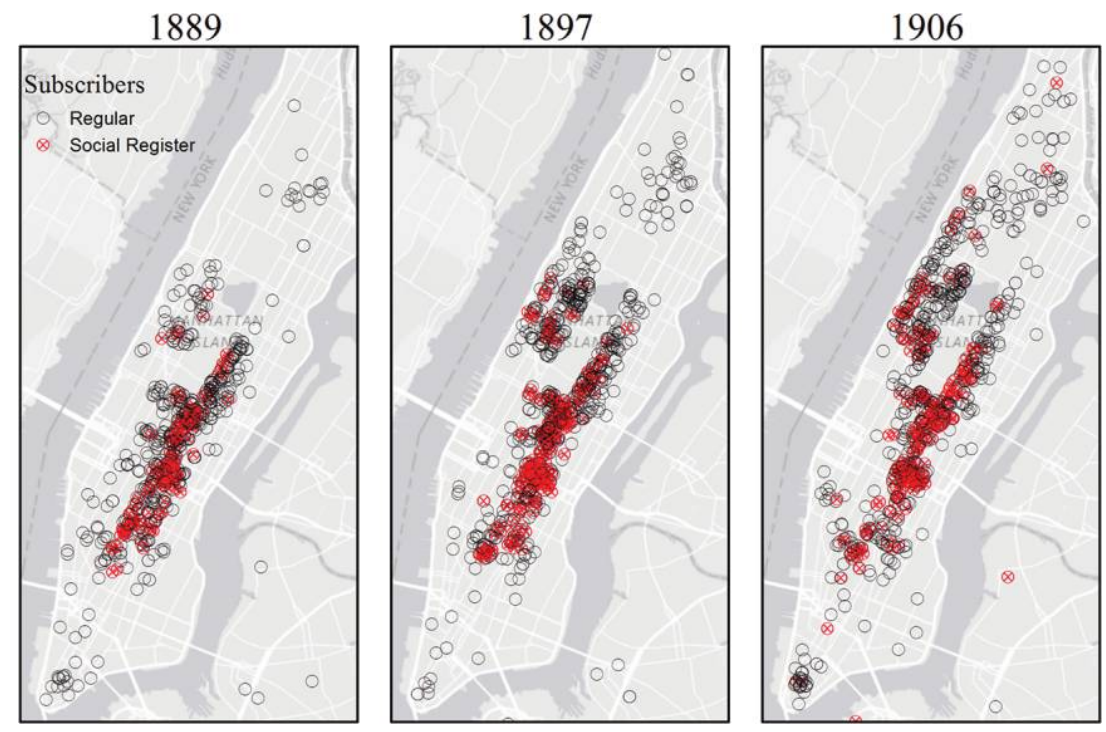

FIG. 8.-Philharmonic subscribers' home addresses in Manhattan, 1889-90, 1897-98, and 1906-7 (red dots = subscribers listed in the Social Register; black dots $=$ other subscribers).

Against this backdrop, figure 11 shows how the occupational background of non-social elite subscribers diverged over time from that of their social elite counterparts. Early on, subscribers in and outside of the social elite were about as likely to come from occupational groups involved in the organization of economic capital. Rapidly, though, subscribers without a Social Register background departed from more elite patrons in terms of their occupational profile. They were not just less social elite; they were also significantly less likely to partake in the conduct of corporate affairs. Only $44 \%$ of them did in 1897 , and no more than $35 \%$ in 1906 - against $55 \%$ and $47 \%$ of social elite subscribers in these respective years. ${ }^{21}$

The growing occupational gap between social elite and non-social elite subscribers can be observed in reverse if we focus on a second series of occupations. While they formed a more heterogeneous cluster than those associated with the possession or organization of economic capital, teachers and professors, clerks and managers, engineers, architects, designers, artists, and writers shared a common feature: they were occupations involving an important educational background. In fact, they formed the bulk of the professional, managerial, and intellectual middle class that emerged in the

${ }^{21}$ Chi-squared tests for the three years confirm that within the population of subscribers, being involved in the organization of economic capital and belonging to the social elite became significantly associated over time. 
1889

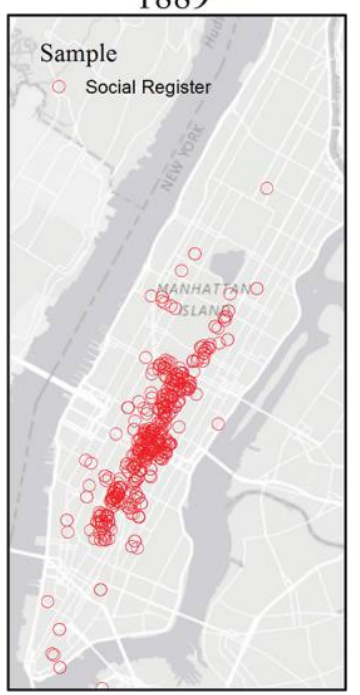

1897

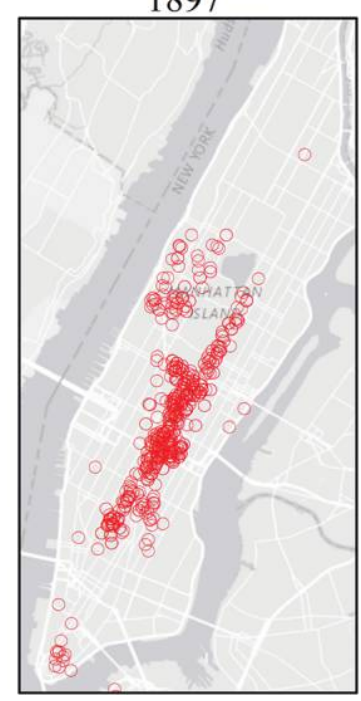

1906

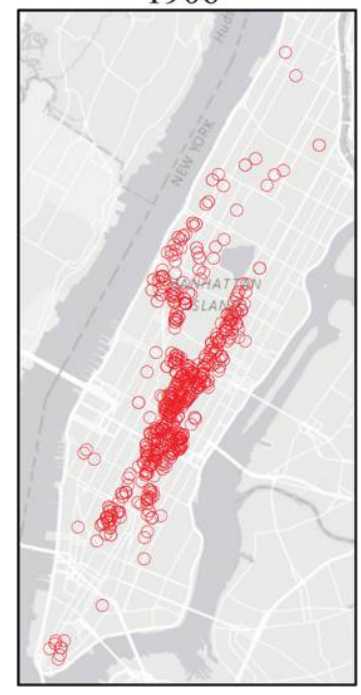

FIG. 9.-The social elite in Manhattan, 1889, 1897, and 1906: home addresses of a 10\% sample from the Social Register.

country around that time (Chandler 1977; Haskell 1977; Gouldner 1979). Figure 12 shows that in the late Gilded Age non-social elite subscribers were always more likely to come from these well-educated occupations. It also evidences how the difference between this group and social elite patrons became more sizable over time. A mere $8 \%$ of social elite subscribers had a background in one of these occupations in 1889, and even though that proportion rose to almost $14 \%$ in 1906, it remained limited. This contrasts with the strong rise in the prevalence of these occupations for non-elite subscribers: from $13 \%$ in 1889 to almost $30 \%$ in $1906 .{ }^{22}$

While social elite subscribers continued to be predominantly characterized by occupations associated with the possession or organization of economic capital, subscribers outside of the social elite increasingly came from backgrounds involving professional and intellectual skills. Possessors or managers of economic capital outside of the social elite, in other words, were increasingly replaced by a professional and intellectual class of educated, non-social elite subscribers.

\footnotetext{
${ }^{22}$ Again here a series of chi-squared tests substantiate the growing departure between social elite and non-social elite subscribers. The departure was actually more pronounced if we focus on teachers and professors, architects, designers, artists, and writers, reflecting the diversity of the emerging managerial and intellectual middle class and the greater proximity of managers or engineers to the economic and social elite.
} 

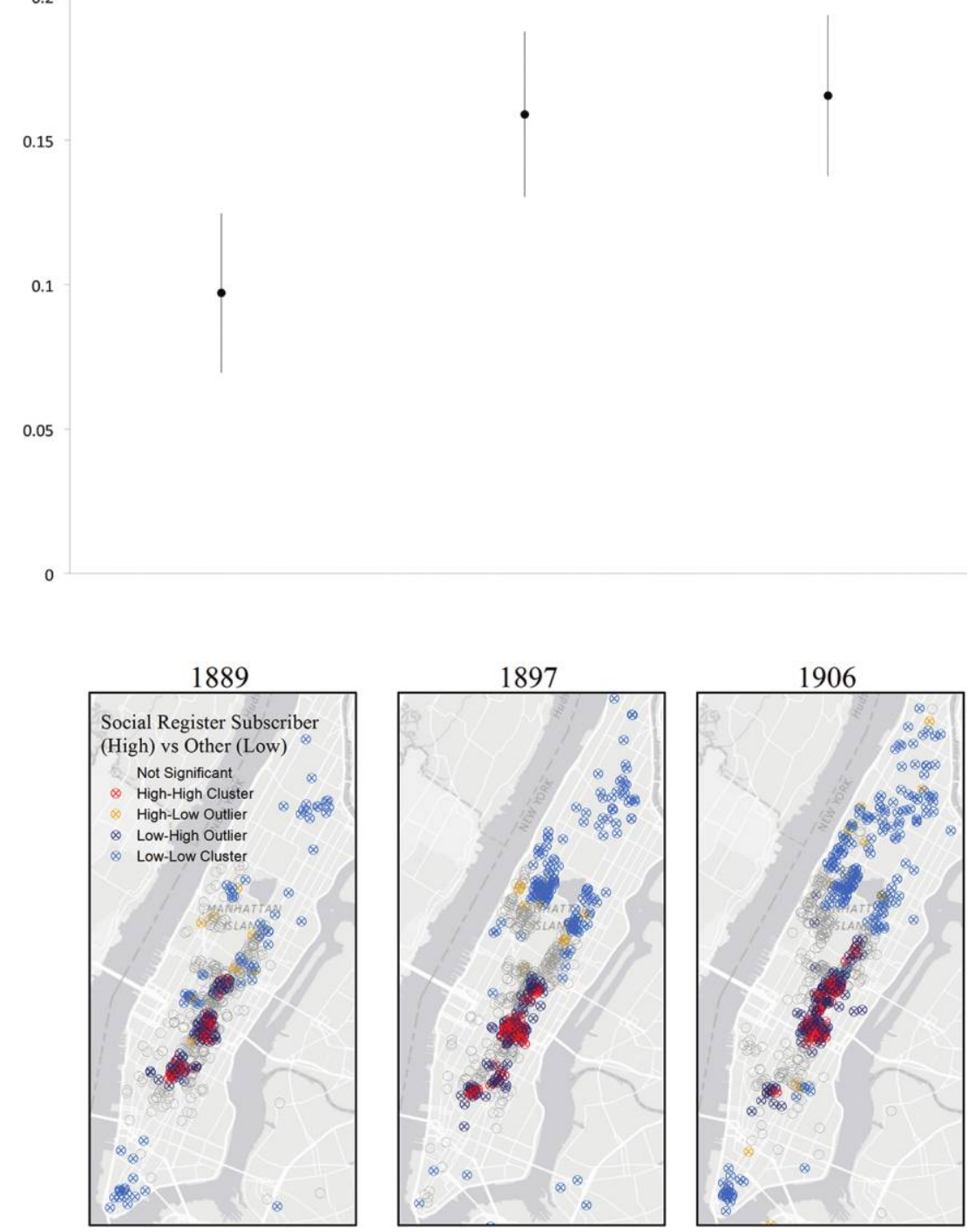

FIG. 10.-Overall residential clustering (Moran's I, with 95\% confidence interval, top panel) and residential clusters of Philharmonic subscribers with (red dots) and without (light blue dots) Social Register representation (bottom panel), 1889-90, 1897-98, and $1906-7$. 


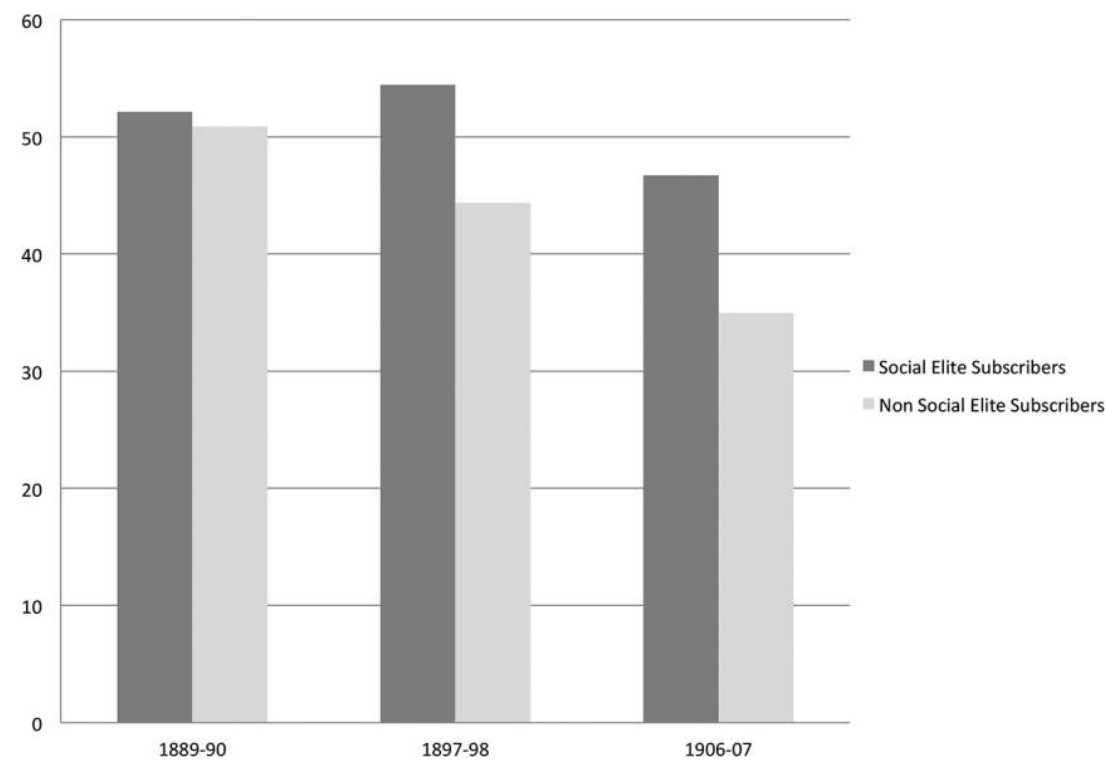

FIG. 11.-Proportion of merchants, manufacturers, bankers, brokers, and corporate lawyers among Philharmonic subscribers, 1889-90, 1897-98, and 1906-7.

Not surprisingly, the areas of residence of this emerging, educated group of subscribers largely overlapped with those of new, non-social elite joiners. Figures 13 and 14 report the residential clustering of subscribers whose occupations were associated with, respectively, the organization of economic capital and a strong education (what we refer to, following Gouldner, as "intellectual" occupations). Again here, clustering is approached as the spatial autocorrelation of subscribers' type of occupation with that of their 25 nearest subscriber neighbors. In both cases that clustering grew from 1889 to 1906: subscribers from different occupational backgrounds were increasingly coming from different city neighborhoods. In fact, while subscribers with economic occupations continued to concentrate on the East Side around the central section of Fifth Avenue, a cluster of educated subscribers gradually emerged in the northernmost areas of the Upper West Side and in Harlem - the same neighborhoods that around that time were sending nonsocial elite subscribers to the Philharmonic.

In the late 19th century, parts of Harlem started to become predominantly populated by German immigrants - many of them Jewish (Rischin 1962; Gurock 2016). Because these groups were typically excluded from the WASP social elite, the emergence of an educated audience hailing from that area may have reflected, not the inclusion of an intellectual and managerial middle class, but the appeal of a very German orchestra to the mem- 


\section{American Journal of Sociology}

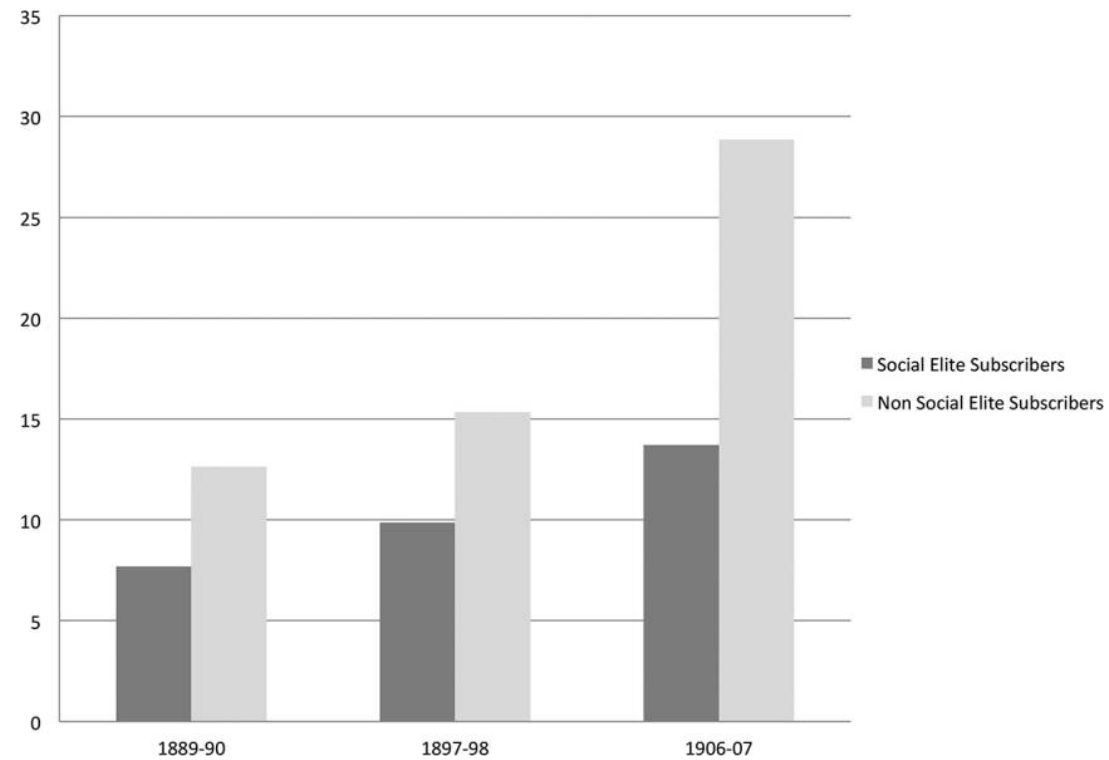

FIG. 12.-Proportion of teachers, professors, clerks, managers, engineers, architects, designers, artists, and writers among Philharmonic subscribers, 1889-90, 1897-98, and $1906-7$.

bers of a growing German community. Several observations challenge that interpretation. First, Harlem's German population, and German Jews in particular, concentrated in East Harlem and around the northern parts of Fifth Avenue, which are not the parts of Harlem where new subscribers typically came from (Gurock 2016, pp. 31-36). Second, an analysis of the names of subscribers suggests that the proportion of German subscribers in fact declined between 1889 and 1906. To perform that analysis, we compared subscribers' last names to the last names of the members of the Deutscher Liederkranz, an organization dedicated to the promotion of German culture in the city that also served as a social outlet for New Yorkers of German origin. ${ }^{23}$ Twenty-one percent of Philharmonic subscribers had

\footnotetext{
${ }^{23}$ Between 1889 and 1906 the Liederkranz had around 1,400 members, the overwhelming majority of whom were of German descent. It was an elite society: the relatively expensive dues were a barrier to working-class German Americans, and the number of Jewish members remained limited (Mosenthal 1897; Nadel 1990). Still, it offers a list of German family names that we can compare to the names of Philharmonic subscribers in various years to gauge the evolution of the share of German subscribers. Importantly, we do not look at subscribers who also belonged to the Liederkranz, but at those whose name was represented in the Liederkranz membership. Geographically, Liederkranz members came from various parts of town, including a strong group from North and East Harlem in the 1890s and 1900s.
} 

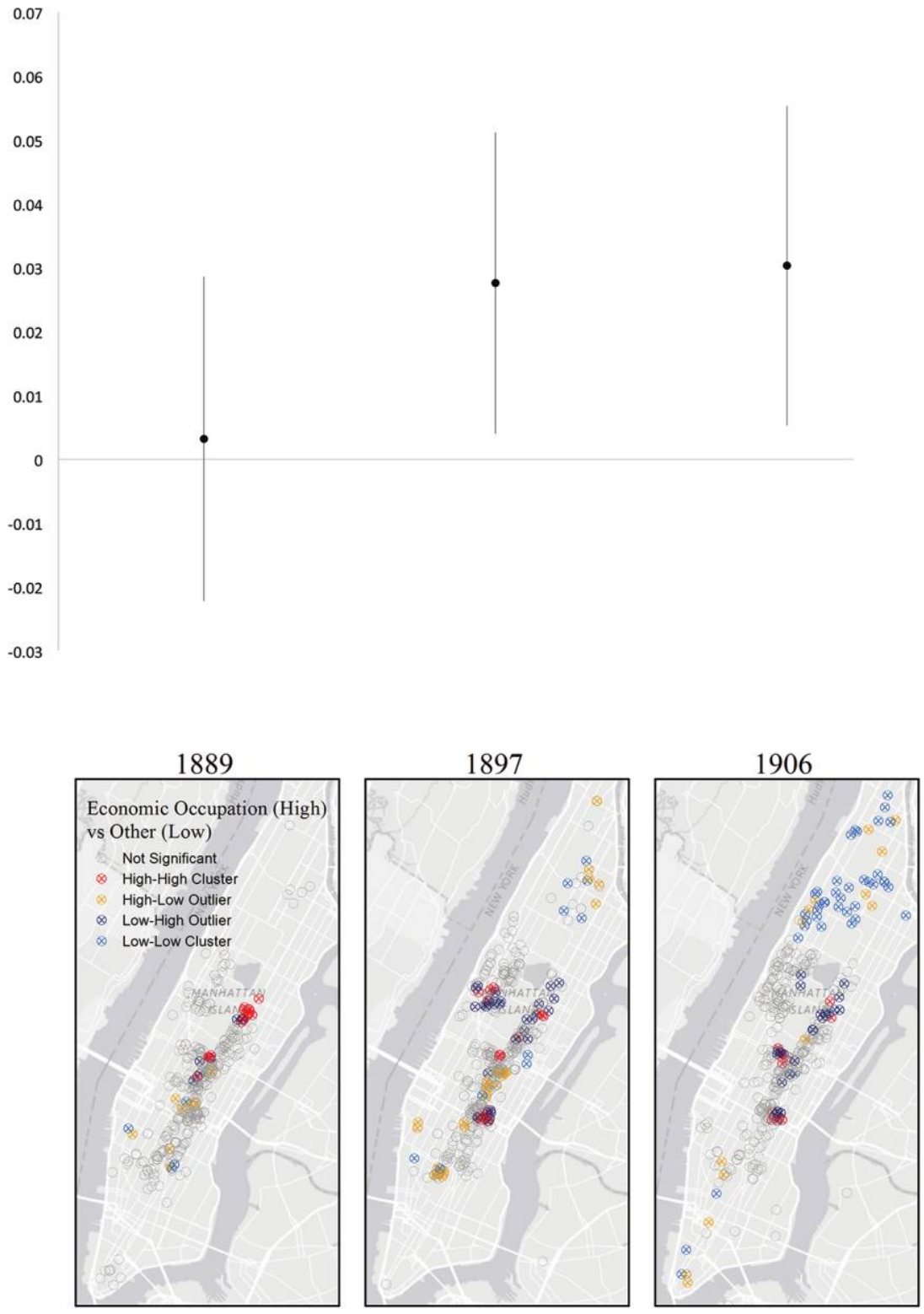

FIG. 13.-Overall residential clustering (Moran's I, with 95\% confidence interval, top panel) and residential clusters of Philharmonic subscribers with economic (red dots) and noneconomic (light blue dots) occupations (bottom panel), 1889-90, 1897-98, and 1906-7. 


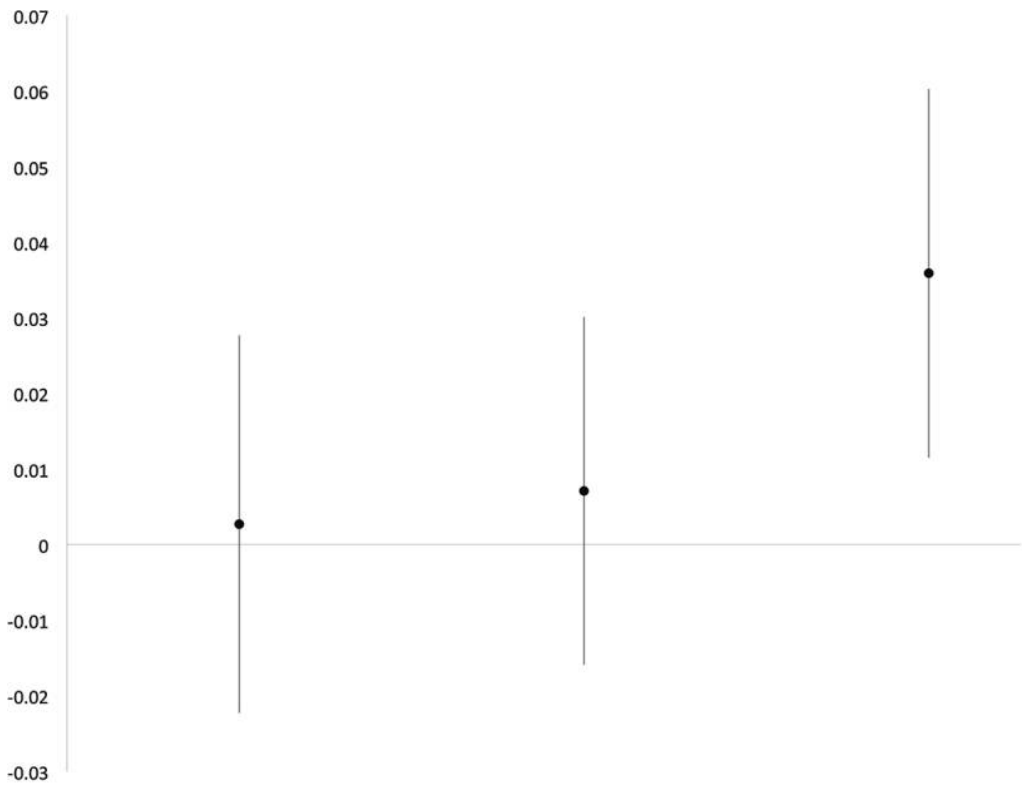

1889

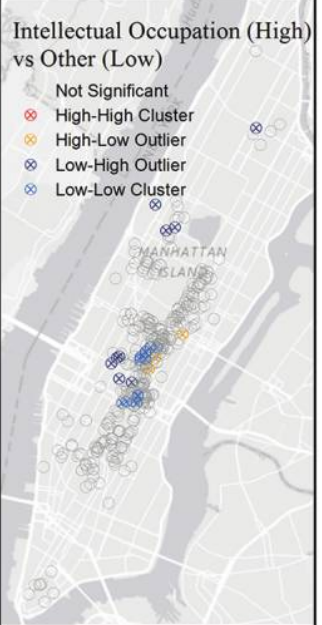

1897

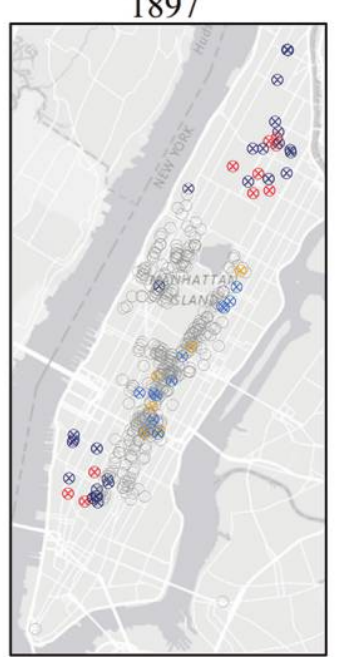

1906

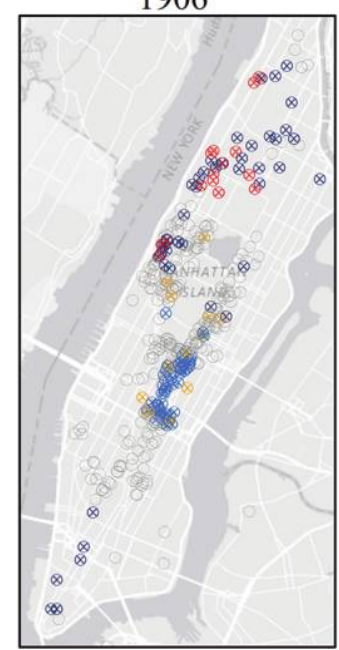

FIG. 14.-Overall residential clustering (Moran's I, with $95 \%$ confidence interval, top panel) and residential clusters of Philharmonic subscribers with intellectual (red dots) and nonintellectual (light blue dots) occupations (bottom panel), 1889-90, 1897-98, and 1906-7.

This content downloaded from 158.143.037.162 on February 04, 2020 03:03:42 AM

All use subject to University of Chicago Press Terms and Conditions (http://www.journals.uchicago.edu/t-and-c). 
names also found in the membership of the Liederkranz in 1889. That percentage dropped to $16.5 \%$ in 1897 and to $14.3 \%$ in 1906 . While these figures probably capture only a fraction of subscribers of German descent, they do not suggest a strong influx of German subscribers in the Philharmonic audience after 1889 .

Writers from that period in fact confirm that large German audiences had already joined in the early 1880 s - that is, immediately after the purification of the repertoire we observe in our data. They noted that in the early days (from the 1840s to the 1870s), attendees to the Philharmonic had not been a "musical crowd." Looking back at this period, the Times's main musical critic, Richard Grant White, observed, "The Philharmonic became fashionable among the younger part of the rich and 'elegant' people who began to throng New York; and the result was that, although rehearsals and concerts were crowded, the seats were filled with a gossiping, gabbling, flirting crowd of finely dressed girls and youths who made it difficult for others to enjoy the music." Yet by 1880 this had changed: "The majority of the audiences," White continues, "are neither New-York nor American by birth and breeding, but chiefly German. When I first attended the rehearsals and the concerts of the Philharmonic Society, no speech was heard among the audience but English — with, of course, such rare exceptions as might occur in London or Liverpool or any large town. Now at these concerts . . . there is a spraching of German all around me, in my in-going, in my downsitting, in my out-coming" (December 26, 1880).

Finally, and further strengthening the notion that new educated subscribers were not in fact German subscribers, we could find no evidence that subscribers with German names had disproportionately managerial or intellectual occupations in our later years. If we also note that in 1906 in particular, educated subscribers chiefly clustered in the northern part of the Upper West Side (fig. 14) - a neighborhood that was not predominantly German - it appears that these new subscribers formed a genuinely new audience, defined by its education and middle-class status rather than by its ethnicity.

The opening of the Philharmonic to this new, educated audience did not go unnoticed. Andrew Carnegie was already celebrating it in his sixtiethanniversary address to the orchestra in 1902: "It is gratifying to look over its lists [of subscribers] and see how from generation to generation, the Philharmonic has been supported by those most devoted to music, many of the best known names being found; so it is also to see the number of new faces which appear" (quoted in the New York Times, April 6, 1902). Three years later the Times was writing of "widening musical interest" in New York and noting that "the public for all sorts of music and the public appetite for it seem to increase as the population of the city increases" (October 22, 1905). And later that year the Times's critic celebrated the reception of classical 
music by the "wage-earners of the city," noting that this was important, since "it is from their ranks that the best students come" (November 5, 1905).

The trend we observe is one of inclusion of an educated, managerial, and intellectual class of non-social elite subscribers. While in the early period the social elite itself never monopolized the concert hall, they tended to be surrounded by others like them. By 1906, however, nonelite subscribers were increasingly diverging from the elite: they tended to live in different neighborhoods and to work in different occupations. This new group, however, did not drive the social elite away from the Philharmonic; if anything, the elite went at higher rates. This makes sense if we consider that the opening of the audience involved educated, middle-class subscribers whose presence testified to the relevance of Philharmonic concerts to social groups outside of the elite. Through the inclusion of these subscribers, high culture became even more of a socially valuable capital. Next, we suggest one further reason that may explain why the social elite stayed: the inclusion of new, nonelite subscribers was segregated.

\section{FROM CULTURAL PURITY TO SEGREGATED INCLUSION}

In the late Gilded Age subscribing to the Philharmonic remained socially distinctive while it also became inclusive of a new group of audience members. To better understand this process we now turn to how these groups attended the Philharmonic. Our hypothesis is that the fine-grained structure of the sitting in the hall explains how enduring distinctiveness was possible in the presence of greater inclusiveness. The transformation of the sitting, we argue, reflected the emergence of a new form of cultural distinction, centered on the way elites consumed culture rather than on the type of culture they consumed.

In a first step we contrast the geographic origin in the city of subscribers of high-quality and low-quality seats. Figure 15 displays how these origins changed over the late 19 th and early 20 th centuries. It shows that while subscribers of first-tier seats continued to come from the most prestigious addresses, over time subscribers in balcony seats increasingly came from Harlem and the Upper West Side of Manhattan. One's seat location within the space of the hall was increasingly reflecting one's residential location in the space of the city.

To further substantiate this view, we measure whether sitting close by in the hall was associated with living close by in the city and how this association evolved over time. We compute the spatial autocorrelation between a subscriber's seat quality and the quality of the seats held by the 25 subscribers who lived closest to that focal subscriber in the city. The top panel in figure 16 shows this autocorrelation going up consistently over time, meaning 
1889

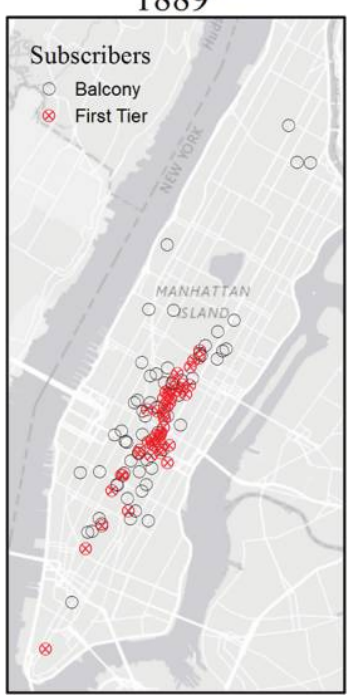

1897

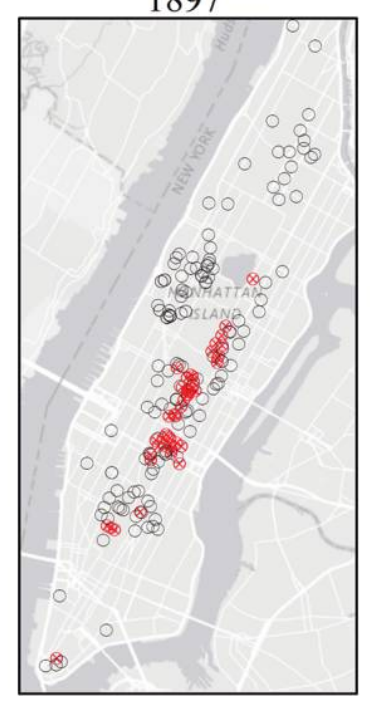

1906

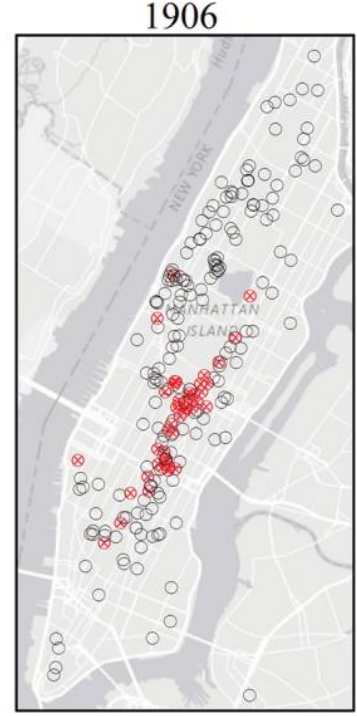

FIG. 15.- Home addresses of Philharmonic subscribers in first-tier and balcony seats

that living close by in the city was increasingly associated with sitting close by in the concert hall. The pattern of sitting within the hall indeed became a mirror of the pattern of living in the city.

Local indicators finally make it possible to observe in greater detail the precise dynamics that drove that evolution toward greater spatial association in seat quality. In the bottom panel of figure 16, bright red dots are individuals who sat in a good seat and whose seat quality correlated positively with that of their subscriber neighbors in the city. Conversely, light blue dots represent individuals who sat in less desirable seats and whose seat quality was positively associated with that of their city neighbors.

Throughout the period the growing association between residential and seat proximity was due in part to East Side subscribers sitting in the hall's more desirable locations. These were typically social elite subscribers. Yet a large chunk of the increase in spatial autocorrelation is explained by subscribers sitting in less desirable sections and who lived on the Upper West Side and in Harlem. A comparison with figures 13 and 14 shows that clusters of subscribers in low-quality seats overlapped with clusters of individuals whose occupations did not pertain to the organization of economic capital. They also encompassed clusters of educated subscribers in managerial and intellectual professions. New members of the audience, in other words, were welcome, but their place in the hall was clearly separated from that of the social elite - whose distinction continued to be read in the location from 


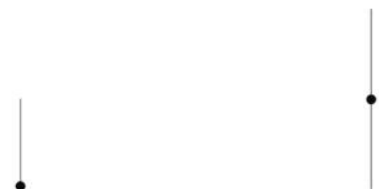

0.1

0.05

0
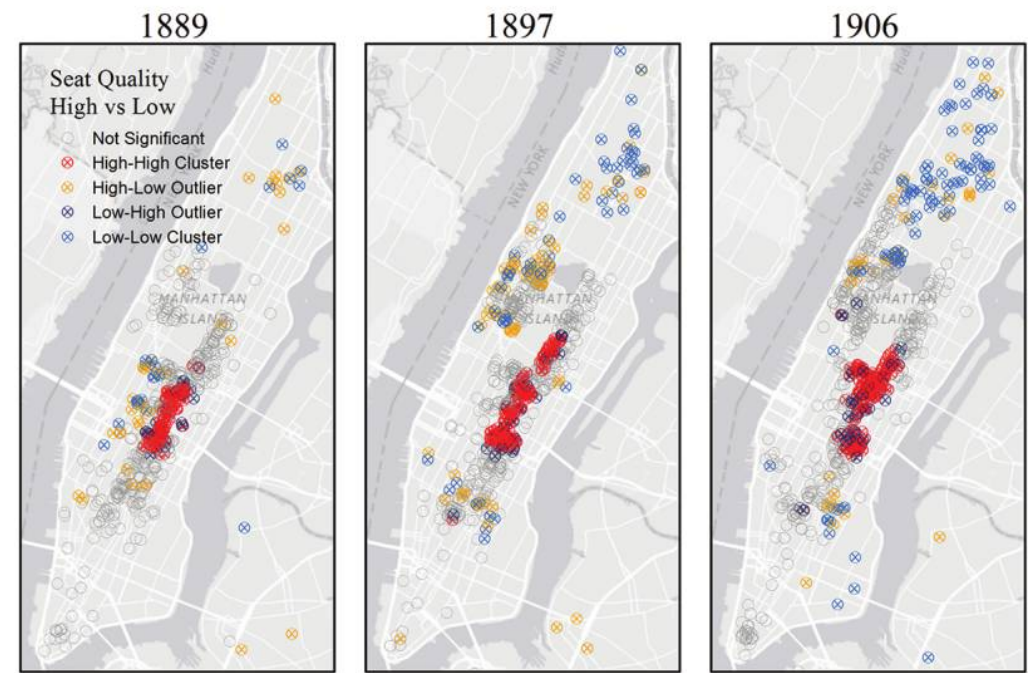

FIG. 16.-Overall residential clustering (Moran's I, with 95\% confidence interval, top panel) and residential clusters of Philharmonic subscribers holding more desirable (red dots) and less desirable (light blue dots) seats, 1889-90, 1897-98, and 1906-7. 
which they enjoyed concerts. ${ }^{24}$ The evolution of sitting patterns at the Philharmonic therefore offers a striking example of segregated inclusion: while the opening of the elite cultural institution to a new, middle-class group was real, it was accompanied by new ways for the elite to demarcate itself from newcomers, thus preserving its specialness and distinction.

\section{CONCLUSION}

On October 24, 1909, the New York Times outlined a plan put into place by the Philharmonic's new conductor, Gustav Mahler, to provide tickets to those who could not afford them:

It is only right, Mahler is quoted as saying, that those who feel they cannot afford to pay the sum necessary to secure a seat at the regular symphony concerts should have the opportunity to hear good music well played at prices within their incomes. .... Students at the universities, music pupils, working people of all sections of this great city are entitled to hear the best classical and modern programmes of orchestral music just as much as others who can easily afford such a privilege. The aim of the Philharmonic concerns will be to education. We do not want to give the public music it does not desire, yet we hope that what we offer will be not only suitable to their tastes, but that it will broaden their musical understanding.

In the late 1900s one of the Philharmonic's goals was to attract and educate an audience beyond the wealthy elite now in charge of its destinies. As we have shown, however, by that time the opening of the concert hall to nonelite patrons was already well under way. The fact and structure of that opening were emblematic of processes that helped to constitute elite culture into a form of socially valuable capital in the Gilded Age. In particular, greater distinctiveness and greater inclusiveness co-occurred at the Philharmonic, enabling the type of culture sponsored by elites to remain socially distinctive while also acquiring broader social currency.

This dual shift toward inclusiveness and distinction happened through the segregated inclusion of an educated middle class - a class that first emerged in American cities in the late 19th century. The uniqueness of that class, we believe, paved a specific pathway for the formation of cultural capital in the United States: in contrast to other contexts, the value of high culture was built not on the cultural authority of the state (Benzecry 2014) but on culture's ability to circulate across social groups while remaining distinctive. Segregated inclusion was central to that phenomenon. It resurfaces later on, as Mahler's plan to broaden the audience of the Philharmonic continues: "Naturally, these concerts [intended to attract working people]

${ }^{24}$ This tightening of the relationship between social position and seat location could also be noted within the elite itself, as shown above in fig. 7 . 
would have to be separate from the regular series." Sharing high culture widely was essential to establishing its currency, but it should not come at the expense of elite distinctiveness. Inclusion was important, but segregation was necessary.

There are three broader implications of our argument. First, we showed that cross-class inclusion was a core feature of the formation of cultural capital in New York - which went on to become a dominant cultural center in the United States. Our approach here joins prior research in suggesting that the constitution of high culture as a form of capital took different paths in different places and that scholars seeking to explain that process should be attentive to its scope conditions - such as the local elite's greater or lesser fragmentation or their overall level of education. Second, an important aspect of our story is that people could pay for their seats at the Philharmonic. Unlike social clubs - into which one had to be accepted - or marriageswhich families typically had to approve - cultural institutions operated on the market, making them uniquely suited for the kinds of inclusion dynamics that we observe. Most importantly, we showed that while exclusive cultural tastes may have helped elites to strengthen their standing in society, the capital on which they garnered advantages from these tastes was built and sustained through interclass participation. This suggests that dynamics of inclusion can play an important role in periods of upper-class consolidation and increasing inequality — such as the Gilded Age.

\section{REFERENCES}

Abbott, Andrew. 1988. The System of Professions: An Essay on the Division of Expert Labor. Chicago: University of Chicago Press.

Almond, Gabriel A. (1939) 1998. Plutocracy and Politics in New York City. Boulder, Colo.: Westview.

Baltzell, Edward Digby. 1958. Philadelphia Gentlemen: The Making of a National Upper Class. New York: Free Press.

Beckert, Sven. 2000. The Monied Metropolis: New York City and the Consolidation of the American Bourgeoisie, 1850-1896. Cambridge: Cambridge University Press.

Beisel, Nicola. 1990. "Class, Culture, and Campaigns against Vice in Three American Cities, 1872-1892." American Sociological Review 55:44-62.

- 1997. Imperiled Innocents: Anthony Comstock and Family Reproduction in Victorian America. Princeton, N.J.: Princeton University Press.

Bender, Thomas. 1978. Community and Social Change in America. New Brunswick, N.J.: Rutgers University Press.

Benzecry, Claudio. 2014. "An Opera House for the 'Paris of South America': Pathways to the Institutionalization of High Culture." Theorv and Societv 43:169-96.

Bledstein, Burton J. 1976. The Culture of Professionalism: The Middle Class and the Development of Higher Education in America. New York: Norton.

Block, Adrienne Fried. 2012. "Thinking about Serious Music in New York, 1842-1882." Pp. 435-50 in American Orchestras in the Nineteenth Century, edited by John Spitzer. Chicago: University of Chicago Press. 
Bourdieu, Pierre. 1984. Distinction: A Social Critique of the Judgment of Taste. Cambridge, Mass.: Harvard University Press.

Burkholder, J. Peter. 1986. "The Twentieth Century and the Orchestra as Museum." Pp. 409-32 in The Orchestra: Origins and Transformations, edited by Joan Peyer. New York: Scribner's Sons.

Chandler, Alfred D., Jr. 1977. The Visible Hand: The Managerial Revolution in American Business. Cambridge, Mass.: Harvard University Press.

Cone, John Frederick. 1983. First Rival of the Metropolitan Opera. New York: Columbia University Press.

Dawley, Alan. 2005. "The Abortive Rule of Big Money." Pp. 149-80 in Ruling America: A History of Wealth and Power in a Democracy, edited by Steven Fraser and Gary Gerstle. Cambridge, Mass.: Harvard University Press.

DiMaggio, Paul. 1982a. "Cultural Entrepreneurship in Nineteenth-Century Boston: The Creation of an Organizational Base for High Culture in America." Media, Culture and Societv 4:33-50.

. 1982b. "Cultural Entrepreneurship in Nineteenth-Century Boston, Part II: The Classification and Framing of American Art." Media, Culture and Society 4: 303-22.

1987. "Classification in Art." American Sociological Review 52:440-55.

1991. "Social Structure, Institutions, and Cultural Goods: The Case of the United States." Pp. 133-55 in Social Theory for a Changing Society, edited by Pierre Bourdieu and James S. Coleman. Boulder, Colo.: Westview; New York: Russell Sage Foundation.

Dowd, Timothy J., Kathleen Liddle, Kim Lupo, and Ann Borden. 2002. "Organizing the Musical Canon: The Repertoire of Major U.S. Symphony Orchestras, 1842 to 1969.” Poetics 30:35-61.

Eisler, Paul E. 1984. Metropolitan Opera: The First Twenty-Five Years, 1883-1908. New York: North River Press.

Gouldner, Alvin W. 1979. The Future of Intellectuals and the Rise of the New Class. New York: Seabury.

Green, Martin. 1966. The Problem of Boston: Readings in Cultural History. New York: Norton.

Gurock, Jeffrey S. 2016. The Jews of Harlem: The Rise, Decline, and Revival of a Jewish Community. New York: New York University Press.

Hammack, David C. 1982. Power and Society: Greater New York at the Turn of the Century. New York: Columbia University Press.

Haskell, Thomas L. 1977. The Emergence of Professional Social Science: The American Social Science Association and the Nineteenth-Century Crisis of Authority. Urbana: University of Illinois Press.

Higley, Stephen R. 1995. Privilege, Power, and Place: The Geography of the American Upper Class. Lanham, Md.: Rowman \& Littlefield.

Horowitz, Helen. 1976. Culture and the City: Cultural Philanthropy in Chicago from the 1880s to 1917. Chicago: University of Chicago Press.

Jaher, Frederic Cople. 1972. "Nineteenth-Century Elites in New York and Boston." Journal of Social History 6:32-77.

. 1982. The Urban Establishment: Upper Strata in Boston, New York, Charleston, Chicago, and Los Angeles. Urbana: University of Illinois Press.

Johnson, Victoria, and Walter W. Powell. 2017. "Organizational Poisedness and the Transformation of Civic Order in Nineteenth-Century New York City." Pp. 179230 in Organizations, Civil Society, and the Roots of Development, edited by Naomi R. Lamoreaux and John Joseph Wallis. Chicago: University of Chicago Press.

Kolodin, Irving. 1966. The Metropolitan Opera, 1883-1966. New York: Knopf.

Krehbiel, Henry E. 1892. The Philharmonic Society of New York: A Memorial. New York and London: Novello, Ewer. 


\section{American Journal of Sociology}

Kremp, Pierre-Antoine. 2010. "Innovation and Selection: Symphony Orchestras and the Construction of the Musical Canon in the United States (1879-1959)." Social Forces 88:1051-82.

Lamont, Michèle, and Marcel Fournier, eds. 1992. Cultivating Differences: Symbolic Boundaries and the Making of Inequality. Chicago: University of Chicago Press.

Lamont, Michèle, and Annette Lareau. 1988. "Cultural Capital: Allusions, Gaps and Glissandos in Recent Theoretical Developments." Sociological Theorv 6:153-68.

Levine, Lawrence W. 1988. Highbrow/Lowbrow: The Emergence of Cultural Hierarchy in America. Cambridge, Mass.: Harvard University Press.

Licht, Walter. 1995. Industrializing America: The Nineteenth Century. Baltimore: Johns Hopkins University Press.

Lizardo, Omar. 2006. "How Cultural Tastes Shape Personal Networks." American Sociological Review 71:778-807.

Martin, George. 1983. The Damrosch Dynasty: America's First Family of Music. Boston: Houghton Mifflin.

Mauskapf, Michael G. 2012. "Enduring Crisis, Ensuring Survival: Artistry, Economics, and the American Symphony Orchestra." Ph.D. dissertation. University of Michigan, Department of Musicology.

Mosenthal, Hermann. 1897. Geschichte des Vereins deutscher Liederkranz in New York. New York: Ringler.

Mueller, John H. 1951. The American Symphony Orchestra. Bloomington: Indiana University Press.

Nadel, Stanley. 1990. Little Germany: Ethnicity, Religion and Class in New York City, 1845-1880. Urbana: University of Illinois Press.

Olenson, Alexandra, and John Voss, eds. 1979. The Organization of Knowledge in Modern America, 1860-1920. Baltimore: Johns Hopkins University Press.

Ostrower, Francie. 1998. "The Arts as Cultural Capital among Elites: Bourdieu's Theory Reconsidered." Poetics 26:43-53.

Parkin, Frank. 1979. Marxism and Class Theory: A Bourgeois Critique. New York: Columbia University Press.

Reingold, Nathan. 1976. "Definitions and Speculations: The Professionalization of Science in America in the Nineteenth Century." Pp. 33-69 in The Pursuit of Knowledge in the Early American Republic, edited by Alexandra Oleson and Sanborn C. Brown. Baltimore: Johns Hopkins University Press.

Rischin, Moses. 1962. The Promised City: New York's Jews, 1870-1914. Cambridge, Mass.: Harvard University Press.

Roy, William G. 1999. Socializing Capital: The Rise of the Large Industrial Corporation in America. Princeton, N.J.: Princeton University Press.

Russell, Charles E. 1927. The American Orchestra and Theodore Thomas. Garden City, N.Y.: Doubleday, Page.

Santoro, Marco. 2010. "Constructing an Artistic Field as a Political Project: Lessons from La Scala." Poetics 38:534-54.

Shanet, Howard. 1975. Philharmonic: A History of New York's Orchestra. New York: Doubleday.

Sloan, Douglas. 1980. "Science in New York City, 1867-1907.” Isis 71:35-76.

Story, Ronald. 1980. The Forging of an Aristocracy: Harvard and the Boston Upper Class, 1800-1870. Middletown, Conn.: Wesleyan University Press.

Tomkins, Calvin. 1989. Merchants and Masterpieces: The Story of the Metropolitan Museum of Art. New York: Holt.

Trachtenberg, Alan. (1982) 2007. The Incorporation of America: Culture and Society in the Gilded Age. New York: Hill \& Wang.

Veblen, Thorstein. (1899) 2009. The Theory of the Leisure Class: An Economic Study of Institutions. Oxford: Oxford University Press. 


\section{Cultural Capital}

Weber, Max. 1978. Economy and Society. Berkeley: University of California Press.

Weber, William. 2001. "From Miscellany to Homogeneity in Concert Programming." $\underline{P o-}$ etics 29:125-34.

. 2008. The Great Transformation of Musical Taste: Concert Programming from Haydn to Brahms. Cambridge: Cambridge University Press.

Wiebe, Robert H. 1967. The Search for Order, 1877-1920. New York: Farrar, Straus \& Giroux. 